\author{
PABLO F. AMADOR MARRERO \\ INSTITUTO DE INVESTIGACIONES ESTÉTICAS, UNAM
}

\title{
De Oaxaca a Canarias: devociones y "traiciones"
}

E L REMOTO ORIGEN DE NUESTRO INTERÉS por el tema de este estudio se encuentra en un texto escrito conjuntamente con el historiador Carlos Rodríguez Morales, el cual, debido a la modestia de su publicación, ha pasado - menos para quienes lo firmamos — prácticamente inadvertido para la historiografía artística. ${ }^{\text {I }}$ Al tratar la imaginería exhibida en las procesiones durante la Semana Santa en La Laguna, Tenerife, islas Canarias, propusimos una nueva catalogación de la talla de Nuestra Señora de las Angustias, la cual adscribimos a las gubias del escultor sevillano Gabriel de Astorga (I804I895). Hasta ese momento — según la bibliografía_- la pieza casi siempre se identificaba como americana, ${ }^{2}$ confundiéndola con aquélla de María Santísima de los Dolores — aunque de igual iconografía_, traída de México por Bartolomé de Mesa y Castilla en I7I5.3 Ahora bien, ciertamente este personaje fue quien la trajo, pero la realidad del encargo para ese momento la creímos diferente, pues Mesa y Castilla debió cumplir una “imposición que en comu-

I. Pablo F. Amador Marrero y Carlos Rodríguez Morales, “Aproximación a la imaginería procesional en Canarias. La Semana Santa de La Laguna y la obra de José Rodríguez de la Oliva”, Escuela de Imaginería, núm. 19, I998, p. 7.

2. En su texto sobre arte americano de 1988, Martínez de la Peńa ya seńala a la Dolorosa mexicana como desaparecida y la sitúa como "obra importante". Domingo Martínez de la Peña, "Esculturas y pinturas americanas en Canarias", en Canarias y América. Gran Enciclopedia de España y América, Madrid, Espasa-Calpe, 1977, p. 2 I4.

3. Alejandro Cioranescu, La Laguna. Guía histórica y monumental, La Laguna, Tenerife, I965, p. 87. 
nicado le dejó don Juan de Molina, llamado el Sahorí”, natural de las islas Canarias, fallecido en la ciudad de Oaxaca. ${ }^{4}$

En ese punto dejamos la investigación de la escultura mexicana debido a su extravío, a la cual se le perdió la pista desde i866 cuando la imagen hispalense comenzó a aparecer en las procesiones, 5 si bien de la misma documentación primigenia conservamos una escueta referencia alusiva al Archivo Notarial de Oaxaca, la cual ofrecerá, junto a la relectura del manuscrito conservado en Canarias, además de nuevos documentos históricos acumulados, las pautas para el presente texto (fig. I).

Pero antes de introducirnos en el tema específico y en vista de las frecuentes reiteraciones encontradas cuando desde fuera del ambiente insular, y de su poco conocida bibliografía, se confunden algunas piezas actuales con las primeras a las que sustituyeron y de las cuales se sabe su origen americano, es necesario hacer al menos una llamada de atención y cautela. Al ejemplo aludido se pueden sumar otros, pero aquí nos quedamos, por su nexo con Oaxaca, con el de la Virgen del Rosario de la localidad de Agüimes, Gran Canaria. Se ha señalado que "la envió de regalo desde Puebla de los Ángeles el deán de Oaxaca, don Juan Fernández Vélez por conducto de su pariente un tal señor Millán", 6 y pasó por diferentes inmuebles hasta recalar finalmente en la parroquia cuyo retablo mayor preside, siendo foco de indiscutible veneración en la comarca. Esta referencia documental marcó la historia de la imagen, pero con motivo del análisis y evaluación de su estado de conservación, el restaurador Julio Moisés Leal la describió en 1969 como "una imagen de fines del siglo XVII o comienzos del XVIII, realizada con toda la técnica de los imagineros sevillanos de finales del siglo XVII". Pese a todo y debido al avance experimentado por los estudios de la escultura americana en el archipiélago y el propio conocimiento de su imaginería, el análisis formal de la talla poco a poco ha ido decantándose por adscribirla a los talleres locales dentro de postulados estéticos afines al último periodo del barroco insular, condicionada ya por incipientes pautas neoclásicas.

4. Amador y Rodríguez, op. cit., p. 7.

5. Idem.

6. Orlando Hernández, "La Señora del Sur", en La Villa de Agüimes y la Señora del Sur, Las Palmas, Gran Canaria, s.e., I959, p. 40.

7. María de los Reyes Hernández Socorro (coord.), "Virgen del Rosario", en Arte hispanoamericano en las Canarias orientales. Siglos XVI/XIX, Las Palmas, Gran Canaria, Casa de Colón/Cabildo de Gran Canaria, 2000, p. 258. 
I. Gabriel de Astorga, Nuestra Señora de las Angustias, anterior a I866. Catedral de Nuestra Señora de los Remedios, La Laguna, Tenerife. Foto: Pablo F. Amador Marrero.

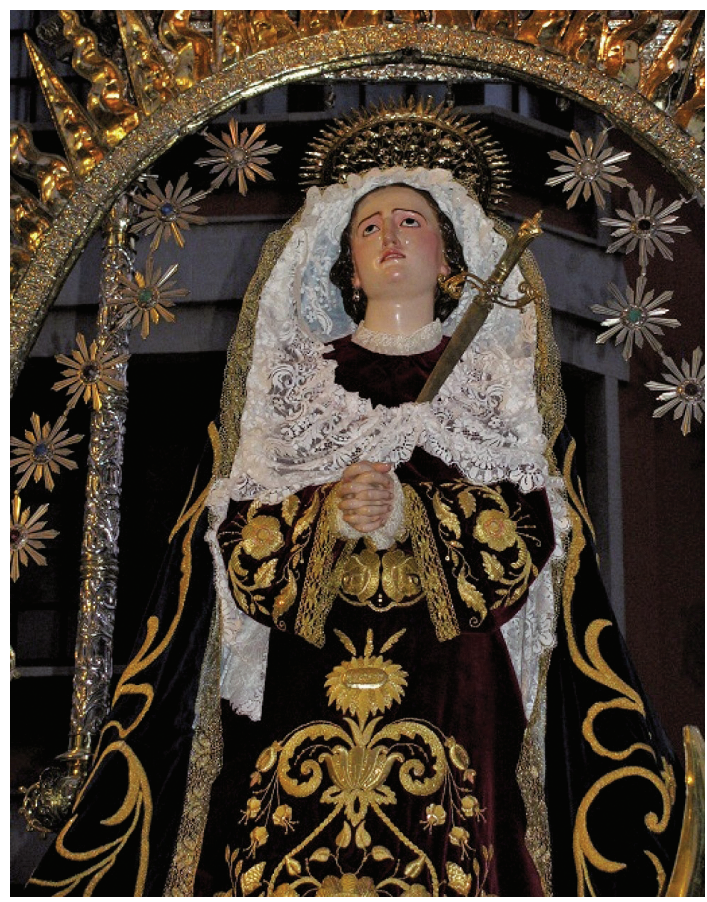

Tras esta digresión y volviendo a nuestro tema de interés, al retomar la documentación original y su análisis obtenemos interesantes datos indicativos ya no sólo del envío de objetos artísticos de la Nueva España a Canarias, alusiones constantes en la bibliografía insular, sino también del protagonismo de muchos isleños residentes en tierras americanas mostrado en el patrocinio de estos lugares, tema apenas explorado en la actualidad. En este punto de la plástica escultórica encontramos un elocuente ejemplo en la figura del obispo canario Domingo Pantaleón Álvarez de Abreu y su cohorte de paisanos cuando ocupó la silla angelopolitana (1739-1763), del cual recientes investigaciones refieren una importante actividad de promociones artísticas no sólo en la catedral poblana. ${ }^{8}$

8. Pablo F. Amador Marrero, "Relaciones artísticas entre Puebla de los Ángeles y las islas Canarias: protagonistas y legados escultóricos”, en Ensayos de escultura virreinal en Puebla de los Ángeles, México, Museo Amparo/Universidad Nacional Autónoma de México-Instituto de Investigaciones Estéticas (en prensa). 


\section{Un pleito tardio}

En un expediente del Archivo Histórico Diocesano de Tenerife se encuentra parte de lo que sin duda, en vista de las alusiones señaladas, debe ser un amplio documento, quizá conservado en el archivo homónimo de Las Palmas de Gran Canaria, aún sin localizar. En unas cuantas fojas se indican las declaraciones de varios personajes respecto de las mandas dejadas por Juan de Molina a su paisano Bartolomé de Mesa y Castilla. Como se alude en la primera foja sin fecha — si bien podría datarse entre agosto y septiembre de I762, fechas señaladas en otras partes del documento-, el fiscal del entonces único obispado de Canarias indicó que Juan de Molina, natural de La Laguna, Tenerife, fallecido en Oaxaca, había nombrado, en una memoria en forma de comunicado y con la finalidad de cumplir sus estipulaciones, a Bartolomé de Mesa y Castilla, "vecino que asimismo fue de La Laguna residente por entonces en Oaxaca” y a punto de regresar al archipiélago, para disponer de todos sus bienes como propios, al no contar con herederos. ${ }^{9}$

Tras señalar algunas mandas - a ellas volveremos-, el fiscal responsable de este primer documento desvela cómo "al fallecer Bartolomé de Mesa sin haber cumplido la manda" se practicaron diligencias con los bienes y la información en poder "de la viuda de don Luis de Mesa, difunto hijo de que fue del expresado don Bartolomé, o de Santiago Penedo, vecinos de La Laguna”. Ante los requerimientos del tribunal eclesiástico y la incautación de bienes solicitados a Ana Díaz de la Guardia, la viuda se amparó por medio de una carta de poder, rubricada en La Laguna el 4 de agosto de 1762 , y pide se le represente ante la Real Audiencia, a lo cual el fiscal eclesiástico al parecer le responde que aguarde la toma de medidas hasta contar con la documentación necesaria y agilizar dichos trámites — Las Palmas, I5 de septiembre de $1762 .{ }^{10} \mathrm{En}$ este punto perdemos toda referencia de lo acontecido con posterioridad con el susodicho pleito, si bien al margen de un documento sobre Juana de Ocampo, mujer de Bartolomé de Mesa, se comprueba que el 23 de agosto de I832 Afonso, escribano público, sacó una copia de la documentación e incluyó a su vez la remitida por Bartolomé de Mesa sobre la fundación de un patronato para cumplir el encargo de Juan de Molina — a la cual también volveremos.

9. Archivo Histórico Diocesano de La Laguna, Tenerife (АнDт), Fondo Histórico Diocesano, legajo/caja I 85 , doc. 73 , f. ir.

Io. Ibidem, ff. $6 \mathrm{r}-8 \mathrm{v}$. 
2. Anónimo canario,

San Gonzalo, siglo Xvi. Antiguo titular de su ermita. Foto: Carlos Rodríguez Morales/ Pablo F. Amador Marrero.

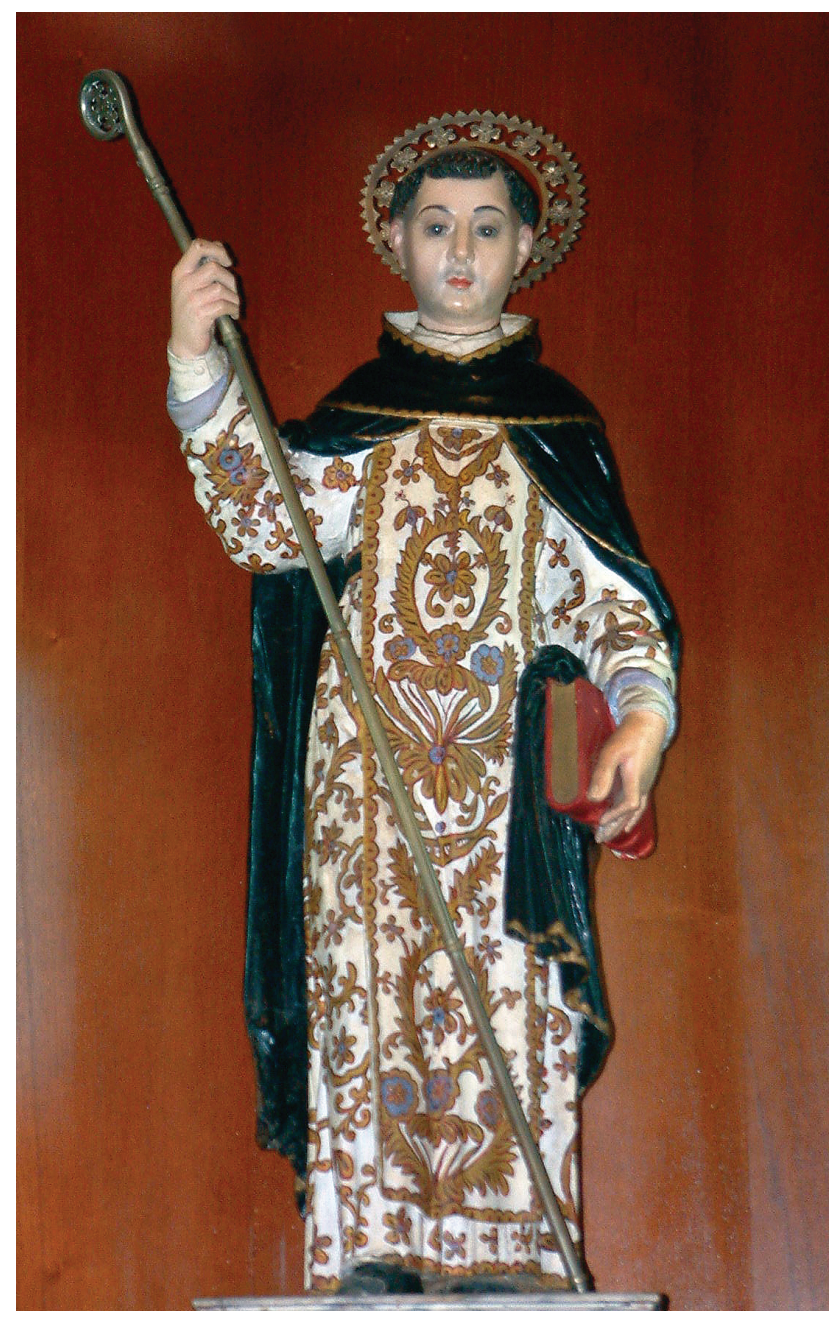

Todo ello a petición "del mayordomo de la ermita de San Gonzalo de Tegueste y mandato judicial", lo que nos hace suponer el alargamiento del pleito hasta bien entrado el siglo XIx (fig. 2). ${ }^{I I}$ De vuelta al texto se recoge, como analizaremos luego, sólo una parte de las referencias a Bartolomé de Mesa y Castilla y su relación con Juan de Molina, si bien ya se desvela aquí el meollo del

I I. Archivo Histórico de Santa Cruz de Tenerife (AHSCT), Protocolo notarial 730, s.f., I2r. 
pleito. Señala el documento cómo en las mandas habían quedado concertados varios encargos píos de Juan de Molina al primero, y aún más, cómo "desde su llegada de América Bartolomé estuvo ganando y disfrutando todos los bienes que se verificaron del dicho don Juan de Molina hasta su fallecimiento y después los tuvo don Luis en la misma forma hasta que falleció y hoy los disfruta la dicha su mujer". ${ }^{22}$ En las preguntas planteadas para el expediente, además de la ya apuntada sobre el disfrute de bienes de Molina, se alude de manera muy sucinta a los encargos de éste respecto de la donación de una talla de Nuestra Señora de los Dolores para la parroquia de Los Remedios - ya referida al comienzo-, el compromiso de la hechura de un retablo colateral, sus imágenes y ajuar para una ermita próxima a la ciudad de La Laguna, además de otras cláusulas tratadas más adelante, ${ }^{13}$ pues antes de profundizar es necesario poner en antecedentes las personalidades y referencias de los actores participantes en una historia finalmente rocambolesca.

\section{Los protagonistas}

Tras explicar el origen de nuestra trama, y luego de haber salido a escena algunos nombres, es pertinente dedicarnos a los protagonistas, comenzando por Juan de Molina y Barrios, ${ }^{\mathrm{I}}$ también llamado el Sahorí, quien como figura será la primera baja de nuestra historia, aunque sus deseos son el eje de nuestro estudio.

Llegaba a su fin el siglo XVII cuando el I7 de agosto de I699, tres días antes de dictar su testamento definitivo, y acaso por la premura impuesta por su padecimiento, el Sahorí otorgó en un corto documento su poder para testar y designó en este primer escrito a su "paisano [Bartolomé de Mesa] persona de toda mi satisfacción y confianza" como su albacea y heredero. ${ }^{15}$ Finalmente el día 20, declarándose "enfermo en cama de la enfermedad que Dios mío Señor ha sido servido darme" así como en posesión de su "entero juicio, memoria y

I2. AHDT, Fondo Histórico Diocesano, legajo/caja II85, doc. 73, f. 2 v.

13. Ibidem, ff. Ir-3r.

I4. Con la adición del segundo apellido, Barrios, lo vamos a encontrar cuando rubrique varios documentos consecutivos en la ciudad de Antequera, actual Oaxaca. Archivo Histórico de Notarías del Estado de Oaxaca (AHNo), Protocolo I5 I, escribanía de Diego Benaias, I8 de noviembre de I698, ff. 545 r-v.

I5. Ahno, Protocolo I52, escribanía de Diego Benaias, I7 de agosto de I699, ff. 473V-475r. 


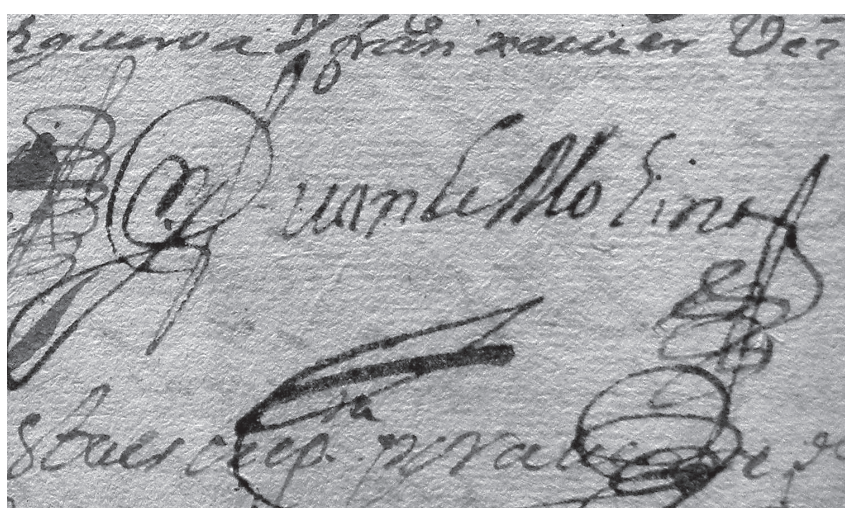

3. Rúbrica de Juan de Molina y Barrios, 20 de agosto de 1699.

Archivo Histórico de Notarías del Estado de Oaxaca.

entendimiento", dictó ante su conocido — como veremos más adelante—, el escribano público de la ciudad de Antequera, Francisco de Quero, sus mandas testamentarias, rubricándolas con mano firme, como lo demuestra la comparación con otras anteriores (fig. 3).

Vecino de aquella ciudad, siguiendo la redacción tradicional de estos documentos, declara su origen nombrándose como capitán y "natural de la ciudad de La Laguna [la entonces capital de Tenerife], en las Islas Canarias". Aludía a continuación a sus padres, ya difuntos y de igual origen, Cristóbal Fernández de Molina y Agustina Díaz Maroto, de quienes no hemos buscado documentación para no extendernos, pero que según algunas referencias debieron tener una posición económica ciertamente desahogada. ${ }^{16}$ Finalmente, como apunta Alejandro Cioranescu, Juan de Molina no sobrevivió al siglo y falleció el 25 de agosto de $1699 .{ }^{17}$

No sabemos por ahora cuándo abandonó Molina su isla natal y terminó recalando en Oaxaca, ${ }^{18}$ pero, en vista de la documentación, los negocios — ser

I6. Ahno, Protocolo 204, escribanía de Francisco de Quero, 20 de agosto de I699, f. I39v. 17. Alejandro Cioranescu, Diccionario biográfico de canarios-americanos, Islas Canarias, Caja General de Ahorros de Canarias (Historia, I4), I992, t. II, H-Z, p. 433.

I8. Hasta ahora, el documento más antiguo donde se le refiere en los protocolos oaxaqueńos lo sitúa ya estante y como vecino de la ciudad el último día de I69I; en él aparece con transacciones de dinero por préstamos. AHNo, Protocolo I 47, escribanía de Diego Benaias, 3 I de diciembre de I69I, ff. 55 Ir-v. 
mercader, como él mismo se nombra- ${ }^{\mathrm{r} 9}$ debieron serle propicios pues declara la posesión de varios inmuebles de cierta identidad en la ciudad. Manteniendo el orden del texto original, el primer inmueble es la casa donde habitaba, la cual además le servía de tienda. ${ }^{20}$ Si bien no la sitúa, quizá corresponda por su privilegiado emplazamiento a una de las casas ubicadas en la esquina del convento de Santo Domingo. Ésta la adquirió en 1695 por 900 pesos de los herederos de Diego Ramírez y su esposa, ya entonces fallecidos. ${ }^{21} \mathrm{Al}$ indicar que la mejoró y con ayuda de la ciudad le llevó agua — por ello, apunta, pagó 30 pesos, para contribuir a las obras públicas - pudiera justificar nuestra hipótesis según la cual se trataba de su residencia y tienda.

Poseía otro inmueble con solar en el barrio del Señor Santo Domingo, no muy distante de los anteriores, adquirido apenas un año antes de su óbito; escriturado el I 8 de noviembre de I698 ante Diego Benegas, pagó por él a Pedro Bermúdez 795 pesos, más el reconocimiento de sus censos. ${ }^{22}$ De estas compras es pertinente señalar el precio alcanzado por sendos inmuebles para demostrar la buena posición económica de Molina. A ello se añade que la cantidad destinada como ayuda en la fábrica del convento agustino era suficientemente elevada para comprar un inmueble como los indicados y situados en la calle Real, de lo cual podemos inferir la alta estima, religiosidad y empeño por aportar a un espacio sagrado tan particular como el que páginas más adelante señalaremos dentro del propio templo agustino, y para nada gratuito en sus intenciones.

A las propiedades anteriores debemos sumar las de Tenerife, de las cuales hay constancia gracias a otros documentos cruzados a publicarse en el futuro. De entrada, una hacienda heredada de sus padres en Tegueste el Nuevo, próxima y perteneciente a su ciudad natal de San Cristóbal, donde se estaba reconstruyendo una ermita, lo cual habla de su importancia y a la que también

19. Ahno, Protocolo I52, escribanía de Diego Benaias, I7 de agosto de I699, f. 473v.

20. Ahno, Protocolo 204, escribanía de Francisco de Quero, 20 de agosto de I699, f. I40r.

2I. Ibidem, f. I4I. La compra se suscribió el 5 de julio de I695, y señala el documento original la proximidad a la calle Real, apuntando su ubicación en la esquina del templo de Santo Domingo, sin duda un lugar bien situado dentro del núcleo alto de la ciudad. AHNo, escribano Diego Díaz Romero, número de inventario 193, I695, ff. I I7r-v.

22. ahno, Protocolo 204, escribanía de Francisco de Quero, 20 de agosto de I699, f. I4Ir. De la lectura del documento original quedan claros la importancia de este inmueble y su emplazamiento en la calle Real. AHNo, escribano Diego Benegas, número de inventario I5I, I698, ff. 543 r-545r. 
volveremos; varios terrenos o suertes de viñas, como las i6 fanegas en el valle de Tegueste el Nuevo, en la parte llamada San Gonzalo; otras tres suertes en la zona denominada El Peñón; una casa en la ciudad, en la calle de la Carrera —una de las arterias más importantes incluso hoy día-; parte de una vińa y casa, legado de su madre, en Tegueste el Viejo, conocido como San Marcos, además de otros tributos y bienes raíces heredados de su padre. ${ }^{23}$

Ya señalamos que Juan de Molina se declaraba mercader, ${ }^{24}$ con tienda abierta en la ciudad de Oaxaca en la misma casa donde vivía; ahí, especifica, se encontraban mercaderías de "Castilla, China y de la tierra". ${ }^{25}$ Sin descartar otros productos, sabemos de su dedicación al comercio de tejidos, pues en el mismo documento, algunos párrafos antes, al reconocer sus deudas con Bartolomé de Mesa y Castilla, indica que sus productos de mercadería eran seda y algodón y a él le pide inventariarlos tras su muerte. ${ }^{26}$ Un año antes, el I8 de noviembre de 1698 , había acudido ante el escribano público y, tras protocolizar la compra de una de sus casas, abre nuevo documento a renglón seguido donde volverá a constar la seda como producto comercial. ${ }^{27}$ Es más, en uno anterior, también junto a Bartolomé, quedaba escriturado ante Díaz Romero el préstamo de "tres mil seiscientos pesos de oro común que en reales de contado les ha dado" el también capitán y mercader Antonio Díaz Maceda, comprometiéndose a devolverlos antes del último día de junio del siguiente año en forma de "grana fina cochinilla de la de este obispado" ${ }^{28}$ — material utilizado para el tinte de tejidos.

De este documento se colige que ambos canarios debieron constituir una especie de sociedad mercantil, algo justificado por dos documentos del mismo ańo, rubricados en los primeros meses, en los cuales comparecen ante el escribano como fiadores. En el primero —-según las descripciones disponibles, pues el libro en cuestión se encuentra perdido-, del I2 de enero de I697, Juan

23. Ahsct, Protocolo notarial 730, copia del documento de la Memoria de Fundación, firmada el I6 de marzo de 1702 en el valle de Oaxaca ante el escribano Diego Díaz Romero, ff. I6v-I7v.

24. En el poder para testar, anterior algunos días a su último testamento, él mismo se nombra así. AHNo, Protocolo I52, escribanía de Diego Benaias, I7 de agosto de I699, f. 473v.

25. AHno, Protocolo 204, escribanía de Francisco de Quero, 20 de agosto de I699, f. I $40 v$. 26. Ibidem, f. I $40 \mathrm{O}$.

27. Ahno, Protocolo I5 I, escribanía de Diego Benaias, I8 de noviembre de I698, ff. 545 r-v.

28. ahno, Notarías de Oaxaca, ante el escribano Diego Díaz Romero, i de diciembre de I697, ff. I96r-v. 
de Molina y Bartolomé de Mesa y Castilla, ambos seńalados como mercaderes, aparecen ejerciendo de fiadores, "en la obligación por la cantidad de 500 pesos de oro común a pagar en los dos primeros años, a favor de la cofradía fundada por Joseph de la Gasca, presbítero capellán de la cofradía del Señor San Antonio de Padua, fundada en la iglesia del pueblo de Jalatlaco (inserto de documento donde se otorga licencia del préstamo)", siendo el solicitante Tomás López Lozano. El 6 del mes siguiente y con el mismo demandante, volveremos a encontrar a los isleños como "fiadores en la obligación por la cantidad de 2000 pesos de oro común a pagar en dos años, a favor de la capellanía que fundó Juan Próspero de Cárdenas". ${ }^{29}$

Respecto de la personalidad de Juan de Molina, si bien contamos con pocos argumentos para trazar una semblanza justificada, queda claro su profundo carácter religioso. Dos años antes de su óbito y quizá sabedor de que nunca regresaría a sus lejanas peñas atlánticas, negociaba con los agustinos de México y luego con los de Oaxaca el patronazgo de la capilla de San Lorenzo de la iglesia de estos últimos, haciéndose con la propiedad de uno de los dos sepulcros y dejando estipulada la manera de proceder en su entierro. ${ }^{30}$ No será gratuito el empeño mostrado por la obtención de dicho patronazgo, pues, como desarrollaremos en el epígrafe correspondiente, mantenía una devoción sincera al santo de su nombre, san Juan, y a su devoto san Lorenzo, estableciendo los mecanismos necesarios para la grandeza de su culto.

Un elemento interesante y digno de destacar consiste en añadir en sus disposiciones, al cumplir con las mandas forzosas, una "ayuda a los gastos que se han de hacer en la beatificación que se espera del venerable siervo de Dios

29. Fojas 68 y 53 respectivamente de ambos documentos. Obtuvimos los extractos donde nos hemos basado de Rosalía Montiel Ángeles (coord.), Archivo Histórico. Notarías de Oaxaca I68 II844, disco compacto, México, ADABI de México, 2006. En Sergio Vásquez Romero, Inventario del Archivo Histórico de Notarías de Oaxaca, México, ADABI, 2006, p. 2 I, aparece el libro correspondiente al escribano público real Diego Benaias referente a I697 con el número Io I, el cual se encuentra extraviado. Respecto a la cofradía de San Antonio de Padua, no hemos encontrado otras referencias en la bibliografía consultada. El pueblo de Jalatlaco — señalamos— quedó integrado en la ciudad de Oaxaca, y es actualmente uno de sus barrios. El templo donde debió establecerse la congregación debió ser el de San Matías, antes de Santa Catalina, pero no se encontraron huellas artísticas de esta iconografía particular. Sobre la iglesia de Jalatlaco véase Oaxaca. Monumentos del Centro Histórico. Patrimonio de la Humanidad, Oaxaca, Gobierno de Oaxaca-Secretaría de Desarrollo Urbano y Ecología, I987, pp. 7 I-78.

30. Ahno, Protocolo 204, escribanía de Francisco de Quero, 20 de agosto de I699, ff. I39r-v. 
Gregorio López", para lo cual destina dos reales de los réditos de sus bienes. ${ }^{31}$ $\mathrm{Al}$ respecto recordemos que, para esos años de finales de siglo, la fama alcanzada por Gregorio López — aún hoy en proceso- quedaba remarcada ya no sólo por su santidad, sino incluso porque sus despojos corporales descansaban al calce de la cruz del Cristo de Santa Teresa, efigie escultórica singular en el ámbito devoto de la ciudad de México y, por ende, determinante para la piedad novohispana. ${ }^{32}$

Difuntos sus padres, siendo él soltero y al parecer sin ningún hermano, porque en su testamento apunta no tener "herederos", es lógico suponer que su "primo" y asociado, por quien tenía gran "satisfacción y confianza", fuera la persona adecuada para, sorprendiéndole el final de sus días, ${ }^{33}$ recibir del Sahorí todos sus bienes, incluso un esclavo a su servicio en su tienda. ${ }^{34}$ Pero el matiz inferido de la redacción del texto, "para que ejecutando el fideicomiso que le dejo comunicado y advertido para el descargo de mi conciencia", 35 hace presuponer - siempre como parte de la hipótesis a establecer al analizar desde diferentes puntos la amplia documentación—, además de reiterar el profundo carácter devoto de Juan de Molina, que su verdadera inquietud era asegurarse ante todo del cumplimiento de sus mandas pías en Tenerife. Por este motivo, nada mejor que condicionar a quien además regresaría a la isla.

Frente a la parca pero sustanciosa documentación encontrada hasta el momento sobre Juan de Molina y Bartolomé de Mesa y Castilla, contamos

31. Ibidem, f. I 4 or.

32. Respecto de la figura de Gregorio López, véase Francisco Losa, Vida del siervo de Dios Gregorio López, Madrid, Imprenta de Juan de Ariztia, I727. Por su relación con el Cristo de Santa Teresa, también llamado de Mapethé o Ixmiquilpan, y por tener incluso un capítulo dedicado a la personalidad de López, véase Alfonso Alberto de Velazco, Historia de la milagrosa renovación de la soberana imagen de Cristo Nuestro Señor Crucificado, que se venera en la iglesia del convento de Santa Teresa la Antigua, México, reimpresa en la calle de la Palma, I845.

33. En la documentación alusiva al patrocinio del altar a san Lorenzo y la propiedad de una de las tumbas de la capilla señala: "es para él y para sus herederos", lo cual sugiere que no descartaba tener descendencia.

34. "Declaro tener por mi esclavo en la tienda de la casa en que habito y en mi servicio y asistencia, un mulato llamado Luis que hube y compré por escritura que para en mi poder y tengo por título del susodicho. Es mi voluntad que dicho esclavo pase por tal a poder de don Bartolomé de Mesa y Castilla. Vecino de esta ciudad a quien se lo dejo para que sea suyo y disponga de él a su voluntad y es la mía que para título del susodicho perciba y se le dé un tanto de esta cláusula copie [...] de este mi testamento." AHno, Protocolo 204, escribanía de Francisco de Quero, 20 de agosto de I699, f. I 40v.

35. Ibidem, f. I $40 v$. 
con algunas referencias más para ayudar a establecer un mayor conocimiento de su perfil biográfico. Descendiente directo de una de las familias más destacadas de la isla, Bartolomé de Mesa Espinosa y Lugo, o Bartolomé de Mesa y Castilla, como él mismo firmaba, fue uno de los siete hijos traídos al mundo por el matrimonio formado por Diego de Mesa y Espinosa, capitán de milicias, regidor de Tenerife en I655 y notario del Santo Oficio de la Inquisición, y Ana de Espinosa y Hoyo. ${ }^{36}$ Fue alcaide del castillo principal de Tenerife, el de San Cristóbal, ${ }^{37}$ y, como su padre, también capitán de milicias. ${ }^{38} \mathrm{El} 30$ de noviembre de 1679 se casó en la iglesia de la Concepción de La Laguna con Juana de Castro y Ayala, quien para el momento de la redacción de sus últimas voluntades, el 26 de diciembre de I7I9, declaraba que de los siete hijos del matrimonio el único sobreviviente era Luis Bernardo, sobre el cual volveremos después al ser heredero y protagonista en el desenlace de nuestra historia (fig. 4).

La estancia en México de Bartolomé debió ser larga y continua. A él, como señalamos antes, ya lo habíamos situado en Oaxaca en $1697^{39}$ y antes posiblemente; no regresó a Tenerife hasta principios de I7I4, según sugiere Cioranescu. ${ }^{40}$ Curiosamente, el mismo año de su residencia en la Nueva España era esclavo mayor de la cofradía del Santísimo Cristo de La Laguna, Tenerife, institución de gran importancia en la vida religiosa insu-

36. Francisco Fernández de Béthencourt et al., Nobiliario de Canarias, La Laguna, Tenerife, Juan Régulo, I952, vol. IV, p. IOI3.

37. En su tiempo, el castillo de San Cristóbal fue la edificación defensiva más importante de la bahía de Santa Cruz de Tenerife; baluarte mandado a construir pronto por el conquistador de la isla, se concluyó en I579, si bien fue continuamente intervenido. En la historia de Canarias, esta modesta fortaleza tuvo sus momentos de gloria al repeler varios ataques, como los emprendidos por los almirantes ingleses Blake (I650), Genings (I705) y Nelson (I797), este último recordado porque en el asalto el famoso marino perdió una mano. De la amplia bibliografía donde se refiere la historia del castillo, nos hemos valido para estos apuntes de Luis Proust y Charles Joseph Pitard, Las islas Canarias. Descripción de Tenerife, Santa Cruz, Tenerife, Ideas, 2007, pp. II4-II7.

38. Fernández, op. cit., p. IOI2.

39. En una escritura del 8 de octubre de I70I, apuntada por Cioranescu, Juana de Ocampo refería la salida de su marido "a Indias ha muchos ańos", razón por la cual solicitaba ante la autoridad pertinente la concesión de una licencia para poder sostener pleitos. Cioranescu, Diccionario biográfico..., op. cit., p. 4I4.

40. Idem. 


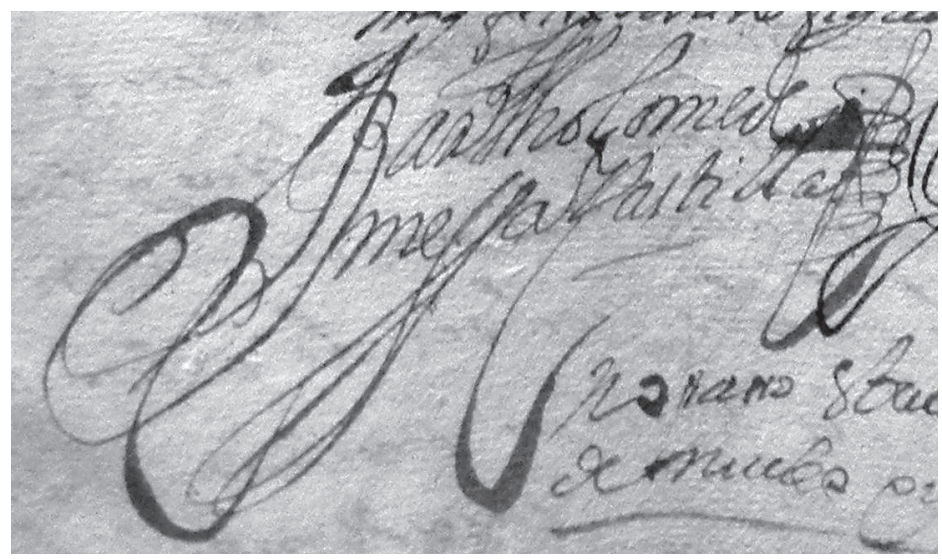

4. Rúbrica de Bartolomé de Mesa y Castilla, I699. Archivo Histórico de Notarías del Estado de Oaxaca.

lar. ${ }^{4 \mathrm{I}} \mathrm{A}$ pesar de sus cargos y en vista de las oportunidades ofrecidas por el comercio americano, se decantó por ello, ${ }^{42}$ lo cual debió serle muy provechoso si atendemos la declaración de Juan de Molina expresada en sus últimas voluntades para pagar determinadas deudas a Mesa y Castilla. ${ }^{43}$

4I. Buenaventura Bonnet y Reverón, El Santísimo Cristo de La Laguna y su culto, La Laguna, Tenerife, Esclavitud del Santísimo Cristo de La Laguna, I952, p. 2 I I.

42. Otros miembros de la familia también se dedicaron al tránsito transatlántico. Por ejemplo, de su hermano Domingo Prudencio se sabe que "fue teniente coronel de milicias provinciales, regidor de Tenerife y alcalde del castillo de San Juan. Viajó a Campeche en 1724 y otra vez en 1727 como maestre del navío Santísima Trinidad, Nuestra Señora del Rosario y con el mismo navío a La Guaira, en 1732". Cioranescu, Diccionario biográfico..., op. cit., pp. 4I4-4I5. Y según el mismo investigador, consta también la presencia de Luis Bernardo, hijo de Bartolomé, en México en i719. Ibidem, p. 4I5.

43. "Declaro soy deudor a dicho don Bartolomé de Mesa y Castilla de tres mil noventa y cinco pesos cinco tomines y medio y restos de cuentas que con el susodicho he tenido, $y$ más le soy deudor de diez caces de seda que me dio a razón de seis pesos y cuatro tomines que todos importan sesenta y cinco pesos y juntamente le debo doce tercios de algodón de a cinco arrobas cada uno que me dio a razón de veinte y un reales arroba, que todos importan ciento cincuenta y siete pesos y cuatro tomines como todo consta en mi libro de cuentas y donde lo tengo asentado, es mi voluntad lo cobre y se lo pague de mis bienes." AHNo, Protocolo 204, escribanía de Francisco de Quero, 20 de agosto de I699, f. I40v. 


\section{El fideicomiso. Dádivas de un indiano}

De regreso al documento motivo de nuestra investigación, aunque de forma fragmentada, comenzamos a aproximarnos al origen de los desvelos de Juan de Molina, en lo que tanto empeño puso a fin de lograr su ejecución en su tierra "para descargo de su conciencia". En lo relativo a las mandas pías, sugiere construir un altar colateral y todo lo necesario a sus imágenes y ajuar en la ermita de San Gonzalo, en Tegueste el Nuevo. De ellas ya sabemos que a la hora de testar Molina, es decir, en I699, el inmueble se encontraba en reconstrucción y formando parte de una hacienda de su propiedad, de donde deducimos su patrocinio. También determina la donación de la imagen de María Santísima de los Dolores colocada "en la iglesia de Los Remedios de aquella ciudad [San Cristóbal de La Laguna], dándole siete lámparas de plata y celebrándole su fiesta anualmente con novena y prácticas", además de resumir las imposiciones relativas a misas por su alma y las de sus padres, la dotación para una huérfana, amén de otra donación particular la cual desvelaremos más adelante. ${ }^{44}$

Si bien el escrito anterior señala el incumplimiento por parte de Bartolomé de Mesa de aquellas mandas, otros nuevos inducen a pensar que, por lo menos en un principio, nuestro presunto culpable Bartolomé sí acometió o intentó realizar tal encargo. Señala Cioranescu que, estando en la antigua Antequera, Mesa remitió a su mujer un "vínculo a su favor" escriturado en aquella ciudad el I6 de mayo de 1702. ${ }^{45}$ Hallada una copia del documento suscrito en Oaxaca en el Archivo Histórico Provincial de Tenerife, conseguimos desvelar parte de las mandas, pues como recurso para cumplir las promesas el propio Bartolomé llevaba a cabo una meticulosa fundación, atestiguando bajo el "nombre de Dios" y haciendo la "señal de la Santa Cruz", que en esta

fundación no ha intervenido por mi parte [...], dolo, fraude, malicia, ni encubierta alguna, sino que la otorgo por convenir así para el descargo de mi conciencia y por dar entero cumplimiento a lo que el dicho don Juan de Molina me dejó comunicado: $Y$ a su cumplimiento, validación, consistencia y firmeza de esta fundación, su

44. Todo queda expresado en las primeras fojas del referido documento: AHDT, Fondo Histórico Diocesano, legajo/caja iI85, doc. 73.

45. Cioranescu, Diccionario biográfico..., op. cit., p. 4I4. 
dotación y erección, obligo, mi persona y bienes habidos y por haber, y doy poder a los sucesores que de ella pueden y deben conocer. ${ }^{46}$

En el inicio del manuscrito oaxaqueño, tras reconocer su intervención como albacea y heredero de los bienes de Molina, reproduciendo parte del testamento original de 1699 donde lo atestiguaba, comienza a relatar las obligaciones del patronato. En conformidad con las cláusulas correspondientes, transcribe las explicitadas en algún documento personal acordado por ambos, el cual no forma parte del testamento en estudio, si bien algunas son referidas tangencialmente. Lo primero versa sobre la nombrada ermita ${ }^{47}$ de la que "manda se perfeccione y acabe en el todo de fábrica, decente y acomodada [...] que está iniciada en una hacienda nombrada La Vega del Horno, que hube y heredé de mis padres y que está en el Valle de Tegueste el Nuevo, jurisdicción de dicha ciudad de San Cristóbal de La Laguna", ${ }^{8}$ haciendo especial hincapié en evitar desatender las necesidades religiosas de los vecinos. ${ }^{49}$

Para esa ermita — como ya adelantaban las preguntas insertas en el documento inicial—, obliga a erigir

en ella un altar con su colateral del señor san Juan Evangelista, Nuestra Señora del Rosario y el señor san Lorenzo; con toda decencia, con sus recaudos de los cuatro tiempos del año, según está dispuesto por nuestra santa madre Iglesia, con su cáliz, vinajeras, candeleros, misal, frontales, manteles, candelas de cera blanca, renovando

46. Aнsct, Protocolo notarial 730, doc. cit., f. 2 or.

47. Este templo, ya desaparecido, era una de las cinco ermitas de la zona de Tegueste según Viera y Clavijo - las otras eran Nuestra Señora del Socorro, San Luis, Santo Domingo y San Pedro de Alcántara-, en José de Viera y Clavijo, Noticias de la historia general de las islas Canarias, Madrid, Imprenta Blas Román, I776, t. III, p. 507. Segregado Tegueste de La Laguna tras las Cortes de Cádiz de I8I2, con la creación de ayuntamientos constitucionales, al primero se le asignan los territorios históricamente adscritos a su parroquia, entre ellos San Gonzalo, del que hoy subsiste únicamente el nombre en el lugar.

48. анsct, Protocolo notarial 730, doc. cit., f. I5v.

49. "que el sacerdote que hubiere de celebrar y decir dichas misas [en relación con las que deja estipuladas por sus familiares] habrá de ser confesor aprobado, y que cuando sea el Evangelio, sea obligado a predicar y explicar la doctrina cristiana a todas las personas que concurrieren a oír la misa y a confesar. Y es mi voluntad que dicha misa sea y se diga a las nueve horas del día, tocando la campana una hora antes, y no lo ignoren, de tal manera que si el presbítero tuviere alguna otra misa por devoción, se diga antes o después, conforme a las oportunidades del tiempo, y a esto se añaden los descargos para las celebraciones". Ibidem, ff. I5r-I6v. 
y perfeccionando cada cosa de las referidas cada que lo pida la necesidad y precisión para ello. Y que se entienda que dichas ermita y colateral han de tener el título de Nuestra Señora del Rosario, cuya santa imagen se ha de colocar en el medio del dicho colateral y a sus lados las de los dichos san Juan Evangelista y san Lorenzo Mártir. ${ }^{\circ}$

Sobre estas primeras disposiciones, Bartolomé dejaba marcado en el vínculo que se "perfeccione y costeen la dicha ermita, colateral y demás bienes necesarios para el culto divino" 5 I En cuanto al templo, ciertamente y en un principio su estudio fue baldío, porque lo derribaron el 20 de junio de 1876 , después de una comunicación a la Santa Sede, recomendando el ya entonces obispado de Tenerife - escindido del de Canarias en la segunda década de ese siglo- que,

para no confundirse, se coloque una cruz en el lugar que ocupara el altar mayor, donde se celebraba la santa misa y se encontraba la imagen de san Gonzalo; que se interesara diligentemente de las personas que pudieran tener el santo — de lo que se infiere que la talla ya estaba fuera de la ermita para ese momento y posiblemente en casa de algún vecino- su devolución y ulterior traslado a la parroquia de San Marcos, para que allí se le dé culto; solicitando también sean devueltas las alhajas y enseres que le pertenecían. ${ }^{52}$

Gracias a un artículo periodístico de Pedro Tarquis, conocemos parte del devenir del patrimonio mueble del modesto recinto, de cuya fachada tenemos constancia por un sencillo dibujo elaborado por el prebendado Pereira Pacheco, quien a su vez señala las reducidas medidas del recinto: siete varas y media de largo por cuatro y media de ancho. ${ }^{53}$ Refiere este investigador los modestos inicios del patrimonio mueble de la ermita. De entre ellos destaca la existencia en el inventario de I578 de "un retablo de pincel dedicado al mártir san Lorenzo",54 imagen inspiradora quizá de la sincera devoción de Juan de Molina, si bien luego desaparece toda referencia a inventarios, lo cual se com-

50. Ibidem, f. I 5 r.

5I. Ibidem, f. I8v.

52. Juan Daniel Darias Hernández, Tegueste. Rincón olvidado. Historia, leyenda y folclore, Tenerife, Ayuntamiento de La Laguna, 1982, p. I30.

53. Reproducido por Darias Hernández, Tegueste..., op. cit., p. I29.

54. Pedro Tarquis, "La ermita de San Gonzalo, siglo xvi. Antigüedades de Tegueste", La Tarde, Santa Cruz, Tenerife, 6 de septiembre de I971, s. p. 
5. Antonio Pereira Pacheco y Ruiz

(La Laguna, Tenerife). Fachada de la ermita de San Gonzalo en Tegueste, Tenerife, ca. I855, dibujo a tinta.

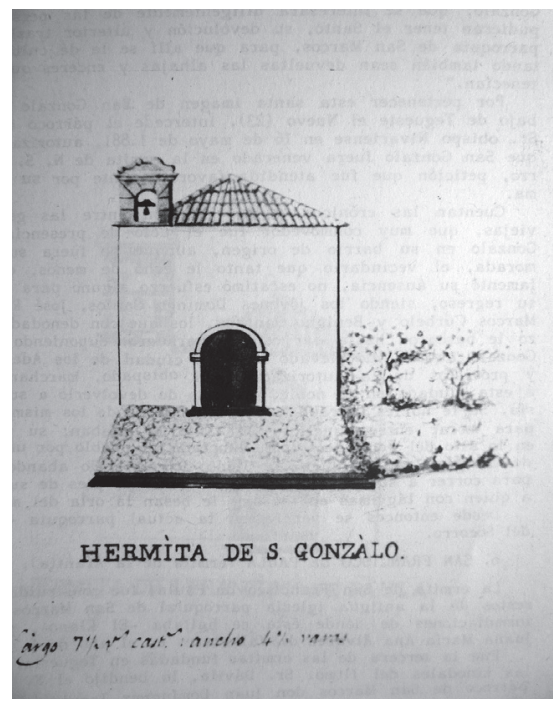

prueba en el único libro de fábrica conservado y en la actualidad depositado en los fondos del Archivo Diocesano de Tenerife (fig. 5).

En este punto de las noticias sobre la ermita debemos hacer una precisión, pues si bien se ha señalado que la misma estaba en reconstrucción a finales del siglo XVII, en un nuevo documento del 28 de septiembre de I72I Diego Lorenzo de Castilla y Palenzuela se declaraba mayordomo del inmueble y expresaba su intención de "fabricarla de nuevo". Continúa refiriendo que si su hijo Rodrigo fuese "nombrado por mayordomo de dicha ermita la fabrique dentro de ocho años", legando que se "abriera un arco en la capilla mayor" y dejando para ello de sus bienes "el valor de ocho pipas de vino que le dejo una en cada un año de los ocho, las cuales darán mis herederos”; a ello añade más adelante la validez del encargo aunque su hijo no recibiera el referido título.55 En este sentido, si bien la comprensión directa del documento no señala un posible mal estado del templo previo y pueda deberse simplemente a su ampliación por la devoción de Diego Lorenzo, tampoco, en vista del modo como se desarrollaron o dejaron de desarrollar los acontecimientos, deducimos el cumplimiento del encargo del Sahorí respecto de la

55. Aнsct, Protocolo notarial, 306, escribanía de José Isidro Uque y Osorio, octubre de I72I, ff. 505V-509r. Pocos días más tarde vuelve a testar: ff. II5V y 5 I2r. 
terminación del templo por parte de Bartolomé, aunque ello no deja de ser una mera conjetura.

De regreso a la línea documental anterior, Juan de Molina consignaba también diversas misas para esta ermita y su retablo, pero no fueron éstas las únicas estipuladas, pues, como continúa e incide en lo ya planteado en el epígrafe sobre la religiosidad de nuestro protagonista, funda también una "memoria perpetua en alabanza, honra y gloria del Cuerpo Sacramentado de Nuestro Señor Jesucristo". ${ }^{56}$ En esta ocasión obliga a celebrar la misa cantada en la octava del Corpus, en la "iglesia de Nuestra Señora de la Concepción o en la de Nuestra Señora de los Remedios, de donde hubiere de salir alternativa la procesión y que mientras se dijere dicha misa se pongan cuatro luces sobre la sepultura de los padres y abuelos del dicho don Juan de Molina". ${ }^{7}$ A lo anterior suma la dotación para una huérfana, probablemente hija de algún hermano de la cofradía del Santísimo de alguna de las iglesias indicadas, quien debería asistir en la misa y participar en la procesión..$^{58}$

Para el cumplimiento de lo anterior, Bartolomé desglosaba un listado detallado de propiedades tributables —en su mayoría heredadas de Molina- y concluía, como es normal en este tipo de protocolo de fundación, con una precisa nómina de la línea hereditaria a cargo de estas mandas. En descargo de nuestro supuesto incumplidor, es justo indicar el registro, en el único libro de cuentas conservado de la ermita de San Gonzalo, de las referencias a los cobros de dotación por parte de Molina después de su óbito, de lo cual deberíamos inferir el cumplimiento de parte de las mandas referidas por Mesa. ${ }^{59}$ Ahora bien, si nos atenemos a la misma documentación, vemos cómo muchos de estos pagos quedan pendientes de cobro; por ello tal vez recaigamos en el problema del incumplimiento, si bien la ausencia de reportes posteriores lleva a suponer su abono, aunque con atrasos, en algún momento. Un dato notable es que posteriormente apareciendo los pagos de mandas de Juan de Molina, pero ahora realizados por Luis Bernardo de Mesa y Castilla, hijo de Bartolomé. No podemos dilucidar mucho al respecto, si bien al parecer hubo cierta preocupación por el cumplimiento, quizá por miedo a la denuncia competente por parte de la autoridad eclesiástica. Al traer de nuevo a estos

56. АнSCт, Protocolo notarial 730, doc. cit., f. I6r.

57. Idem.

58. Ibidem, ff. I6r-v.

59. AHDT, Fondo parroquial de Nuestra Señora de la Concepción de La Laguna, Fondo Asociado, Ermita y cofradía de San Gonzalo de Amarante, lib. I. 
últimos y mencionar los posibles incumplimientos, regresando a la denuncia presentada, es pertinente señalar cómo el responsable religioso previene "que sólo por algunos años se practicó la disposición en cuanto a la huérfana”. ${ }^{60}$

Volviendo al vínculo, curiosamente, y como indica Cioranescu, éste sería en beneficio de su mujer y en perjuicio de su hijo Luis Bernardo, si bien al regreso de Bartolomé él mismo anularía el patronato el io de febrero de $1715,{ }^{61}$ aunque a ello le haremos en su momento las apreciaciones pertinentes.

Tal como hemos visto, nada se apunta en cuanto a la donación de la imagen de bulto de Nuestra Señora de los Dolores, a la cual se refiere el texto primigenio: "Primeramente como es cierto que don Bartolomé de Mesa trajo de la América una imagen de María Santísima de los Dolores y la colocó en la iglesia de los Remedios de aquella ciudad dándole siete lámparas de plata y celebrándole su fiesta anualmente con novena y prácticas, todo lo cual hacía por imposición que en comunicado le dejó don Juan de Molina llamado el Sahorí". ${ }^{62}$ De esta noticia, los elementos por analizar son varios. Nuevamente, y en descargo de nuestro presunto culpable, el hecho de que si bien está en el expediente y por ello el juez eclesiástico lo debió aludir como posible incumplimiento, Bartolomé sí acató por lo menos algún tiempo las disposiciones supuestamente encomendadas a él "celebrándose su fiesta anualmente". Por otra parte, la generosidad del benefactor ya no sólo se traduce en la donación de la imagen encargada a él por Molina, sino que a su vez le donó siete lámparas de plata, ${ }^{63}$ dádivas nada frecuentes por su cantidad y supuestamente estimadas para velar en recuerdo de los siete dolores de María. Respecto de estas piezas suntuarias, ya no constan en la capilla de la Dolorosa en I8I9. No en vano, en su manuscrito de aquel año sobre la erección del templo, el prebendado Antonio Pereira Pacheco y Ruiz advierte la existencia de una sola. ${ }^{64}$ Probablemente las mismas sucumbieron, como otros tantos enseres, al buscar

6о. АнDT, legajo/caja II 85 , doc. 73 , f. 2 r.

61. Cioranescu, Diccionario biográfico..., op. cit., p. 4I4.

62. АнDT, legajo/caja I I85, doc. 73, f. 2r. También señaladas por Cioranescu, Diccionario biográfico..., op. cit., p. 4I4, y por Adolfo Arbelo García, Las mentalidades en Canarias en la crisis del antiguo régimen, Santa Cruz, Tenerife, Centro de la Cultura Popular Canaria/Ayuntamientos de La Laguna e Icod, I998, p. I75, n. I4.

63. Véase Cioranescu, Diccionario biográfico..., op. cit., p. 4I4.

64. "del arco grande toral pendían cinco lámparas de plata, otra en el centro de la bóveda, otra en la capilla de Dolores." Antonio Pereira Pacheco y Ruiz, Noticia histórica de la erección de la santa iglesia catedral de San Cristóbal de la M. N. y L. ciudad de La Laguna de Tenerife, manuscrito conservado en la Biblioteca de la Universidad de La Laguna, Tenerife, I8I9, f. 33v. 
recursos con los cuales sufragar los gravosos costos causados por la preparación de la antigua parroquia para acoger su nuevo cometido como catedral.

Con el fin de profundizar en ello debemos ir al testamento del hijo de Bartolomé, Luis Bernardo de Mesa y Castilla, personaje que ya hemos nombrado y quien, como se indicó, al iniciarse el pleito por incumplimiento ya había fallecido.

Ytten expresan los otorgantes se les comunicó por dicho don Luis que por cuanto el citado don Bartolomé de Mesa, su padre, trajo de México a las imágenes de Nuestra Seńora de los Dolores y san Judas, que colocó en la iglesia parroquial de Nuestra Seńora de los Remedios de esta ciudad, a quien tenía gran devoción, y puso a su costa la plata que guarnece su nicho, en donde está el Santísimo Cristo, y dándole asimismo las siete lámparas de plata que se hallan en su capilla, y a quien costeaba y hacía la función, dándole lo necesario a dicha santísima imagen, y a quien el dicho don Luis tenía asimismo devoción; y así era su voluntad se diese por su heredera o herederos perpetuamente para siempre jamás cien reales corrientes a el mayordomo o mayordomos de cofradía de dicha santísima imagen de los Dolores para ayuda de los costos de su santísima novena y prácticas que se le hacen, los que era su voluntad se pagasen sin detención perpetuamente de sus bienes, y especialmente de la casa de su habitación, suerte del Peńón y vińa inmediato a San Gonzalo, que heredó dicho su padre de don Juan de Molina, siendo como ha de ser obligación de dichos mayordomos mandar decir en cada un ańo una misa cantada el Viernes de Dolores. ${ }^{65}$

A tenor de esta referencia, sólo en parte conocida, y volviendo sobre nuestros pasos, quizá debamos cuestionarnos algunos argumentos vertidos en aquel primer artículo, origen de nuestro interés. Se plantean aquí varios asuntos afines a la casuística de la propia investigación, más aún por la dificultad añadida de lo fragmentado y distante de sus testimonios escritos. Si evaluamos las referencias hasta ahora encontradas sobre la imagen mariana, nada señala Juan de Molina en su testamento, algo extraño si nos atenemos al cuidado observado por él en las anotaciones de sus mandas. Tampoco Bartolomé de Mesa y Castilla la apunta en la documentación remitida al archipiélago como parte de la fundación, y sólo cuando entra en liza Luis Bernardo de Mesa y Castilla, ya tarde, será cuando tengamos apuntes más concretos. A ello hemos

65. Ahpsct, Protocolos notariales, 96I, escribanía de Juan Agustín de Palenzuela, ff. 62v$63 \mathrm{r}$. 
de sumar otra referencia directa, la cual hasta ahora no hemos tomado muy en cuenta: la donación de una imagen de san Judas Tadeo. Cioranescu, en su guía artística sobre la ciudad canaria, al describir la catedral actual, dice:

La capilla siguiente está dedicada a Nuestra Señora de los Dolores. Su retablo, de estilo neoclásico, pero de líneas menos puras que las del anterior, había sido al principio de una Virgen de las Mercedes, según parece resultar de sus motivos decorativos. La imagen de la Virgen de Dolores, de vestir, así como la de san Judas Tadeo, había sido traída de Méjico y donada a la confraternidad de los capellanes de la iglesia, en I7 I 5, por don Bartolomé de Mesa y Castilla. Hasta I904 estuvo en la capilla colateral del Evangelio; probablemente venía en sustitución de otra imagen de la misma advocación, patronato de los Franchi Alfaro, y que en el siglo xviI ocupaba el mismo altar (fig. 6). ${ }^{66}$

Al concretar este investigador el presente de la o las piezas a dicha congregación por Mesa y Castilla sin matizar su posible correspondencia a una donación, cuando ya hemos comprobado en otros estudios su cuidado en los apuntes y referencias, lleva a suponer la ausencia de la misma en la documentación consultada por él. Además, si nos ceñimos al testamento de Luis Bernardo, el matiz consiste en que ellos, tanto su padre como él, son los devotos de dicha advocación. Es más, sin salir de este jugoso párrafo, el recurso explícito de "puso a su costa" no dejaría lugar a dudas que son consecuencia de Bartolomé. Pero si ya en otra de las piruetas de este texto hemos vuelto al principio, ¿por qué el juez eclesiástico señala la donación de la Virgen por Molina y por qué no refiere el san Judas? Aunque deberemos esperar futuros hallazgos de nuevos y esclarecedores escritos, si nos atenemos a la documentación requerida por dicho juez eclesiástico a la viuda de Luis Bernardo o la propia notaría oaxaqueña, ya conocida de manera tanto directa como cruzada, no encontramos los argumentos para poder identificar a éste como el elemento de la "traición" que buscamos e indica el tribunal canario. Es justo aquí recapitular y establecer, dándole el beneficio de la duda, lo planteado en el añejo artículo y restituir la personalidad de Bartolomé como promotor y devoto de la perdida efigie mexicana de los Dolores.

En este punto e indistintamente de quién fuera el verdadero promotor de la llegada de la imagen mariana a la entonces parroquia de los Remedios, vale

66. Cioranescu, La Laguna..., op. cit., p. 87. 
60 PABLO F. AMADOR MARRERO

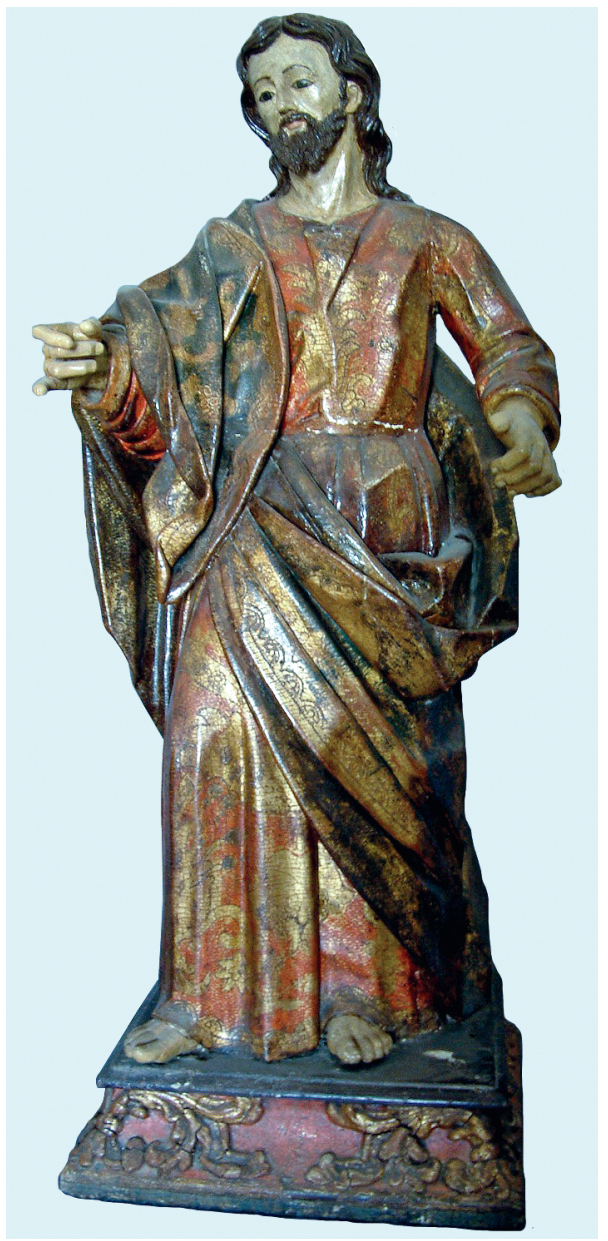

6. Anónimo novohispano, San Judas Tadeo, anterior a I7I5. Depósitos de la Catedral de Nuestra Señora de los Remedios, La Laguna, Tenerife. Foto: Pablo F. Amador Marrero.

la pena hacer una corta digresión respecto del interés suscitado por la pervivencia de un antiguo traje - corpiño y falda-, actualmente perteneciente a la Virgen de las Angustias, del cual ya desde un primer momento supusimos pudiera tratarse de parte del antiguo ajuar de Nuestra Señora de los Dolores y quizá por ello de procedencia americana. Siguiendo a Jesús Pérez Morera, especialista en la materia, se trata de un rico tejido labrado en seda con hilos metálicos entorchados en oro, ligamentos de sarga o diagonal y cuyo fondo 


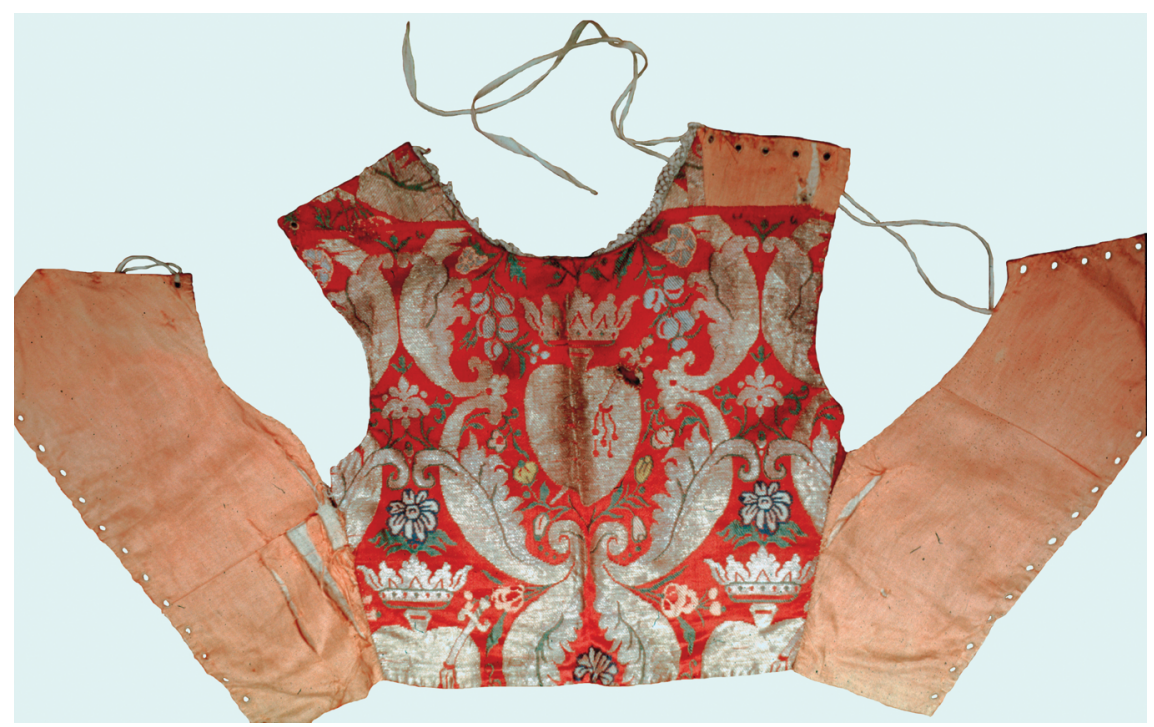

7. Anónimo novohispano, corpiño del traje de Nuestra Señora de los Dolores, primer tercio del siglo xviır, tejido brocado. Catedral de Nuestra Señora de los Remedios, La Laguna, Tenerife.

quizá corresponda con raso. La particular unidad decorativa donde se trazó en el telar describe una composición en red de amplios rombos centrados por un corazón coronado y atravesado por el simbólico puñal, enmarcado a modo de escudete por hojas de acanto de volutas contrapuestas y ramilletes espolinados de flores y frutos, los últimos asimétricos y desiguales. El dibujo bebe de ciertos modelos frecuentes en el siglo xvir pero, como de nuevo señala el aludido investigador, no tiene referentes directos ni en las islas ni en la Península, atestiguando en mayor medida su procedencia indiana. Aquí no podemos olvidar que, aunque aún es un tema poco atendido, la Nueva España contaba ya entonces con una notable producción textil a la que Oaxaca no era ajena (fig. 7).

En cuanto al singular diseño condicionado por la iconografía, éste tiene otros referentes en la imaginería novohispana, aunque en sendas ocasiones se trata de ornamentación estofada y no de textiles en sí, además de ser posteriores. Al primero lo encontramos en la rica decoración de la talla de la Dolorosa que forma parte del conjunto escultórico del Calvario, donado por los Medina para su capilla en la iglesia conventual de Regina Coeli, ubicada en 
el centro histórico de la ciudad de México. ${ }^{67}$ Del otro ejemplo, también para la misma iconografía mariana, ya hemos adelantado algunos trazos cuando tratamos los revestimientos policromos de la parroquia de Santa Prisca y San Sebastián de Taxco, Guerrero. ${ }^{68}$

Antes de seguir con nuestro último protagonista, Luis Bernardo de Mesa, y aprovechando que hemos nombrado la talla de san Judas Tadeo, vale la pena dedicarle algunas líneas, a la espera de un próximo estudio más detallado. Donada a la confraternidad de los capellanes, recibió culto en el mismo retablo de la efigie mariana, ${ }^{69}$ y no creemos que su nicho, al igual que el de la Dolorosa, fuera también guarnecido de plata como señala Cioranescu y se desprende del documento. ${ }^{70}$ Dicho retablo presidido por el Cristo de los Remedios, era objeto por igual de la devoción de Bartolomé y su hijo, y en él debieron perdurar un largo tiempo hasta ser trasladadas finalmente, con motivo de la edificación de la actual fachada del templo a principios del siglo XIX, a un colateral de la nave del Evangelio ${ }^{71}$ y luego se diseminaron: el Cristo preside el tabernáculo neoclásico en el altar mayor; la Dolorosa, como hemos dicho, fue sustituida, emplazándose la nueva hechura sobre una repisa lateral del retablo del Señor a la Columna; a su vez, el san Judas recaló durante muchos años en el seminario diocesano ${ }^{72}$ y en la actualidad forma parte de los depósitos del futuro museo catedralicio. Respecto de esta imagen y con motivo de su restauración, en la ficha de catálogo editado con tal motivo se indicó su procedencia como "escuela española de finales del siglo Xvir" ${ }^{73}$ Por nuestra parte, su estudio nos

67. En este caso, en el traje de la Virgen se combinan corazones resplandecientes en los cuales confluyen siete grandes puñales, alusivos a los Dolores de la Madre, y diferentes flores también simbólicas. Un estudio al respecto lo podemos encontrar en Elsa Laura Ogaz Sánchez, "El conjunto escultórico del Calvario en la iglesia de Regina Coeli", tesis de maestría, Universidad Nacional Autónoma de México-Facultad de Filosofía y Letras, 20I I, pp. 50-5I.

68. Pablo F. Amador Marrero, "Del beneficio de la plata y sobre el refulgente oro. Apuntes acerca del color y su lectura en la parroquia de Taxco", Diario de Campo, Boletín Interno de los Investigadores del Área de Antropología, núm. I03, marzo-abril de 2009, pp. 6I-69.

69. Martínez, Esculturas y pinturas..., op. cit., p. 214.

70. Cioranescu, Diccionario biográfico..., op. cit., p. 4I4.

7I. Carlos Rodríguez Morales, "Cristo de los Remedios", en Imágenes de fe, La Laguna, Tenerife, 2000, p. 36.

72. Martínez, Esculturas y pinturas..., op. cit., p. 214; Pablo F. Amador Marrero, El ajuar del cielo. Relaciones canario-americanas en la escultura a través de sus procesos policromos, Gran Canaria, Museo Casa Colón, 2007, pp. 31 y 173 (inédito).

73. Rafael Delgado, Exposición. Restauraciones en Tenerife 1973, Santa Cruz, Tenerife, Cabildo Insular de Tenerife, I973, s.p. 
ha llevado describirla como una pieza de cierta singularidad y posiblemente fuente de inspiración de escultores locales, según lo establecimos al compararla con la producción del escultor Sebastián Fernández Méndez el Mozo (I70oI772), ${ }^{74}$ lo cual en definitiva incide en las afinidades y gustos compartidos de los isleños con los americanos.

\section{Un posible desenlace}

Las reiteradas llamadas de atención sobre Luis lo llevan de manera inexorable a convertirse en el último de los actores principales de nuestra trama. Luis Bernardo de Mesa y Castilla fue, como su padre, capitán de milicias y alcaide, pero en su caso de otro de los castillos del puerto de Santa Cruz, el de San Juan, ${ }^{75}$ y también esclavo mayor del Cristo de La Laguna. ${ }^{76}$ Señala Cioranescu, y se comprueba por la documentación notarial, que Bartolomé no lo consideró entre los primeros para el vínculo de fundación encargado en 1702 con el fin de cumplir las mandas de Juan de Molina, lo cual recayó en primer lugar en Juana de Ocampo, su legítima mujer, y, tras ella, en varios de sus hijos, tal vez en línea de nacimiento. ${ }^{77}$ Pero al retornar Bartolomé a su tierra natal en I7I4, habría de cambiar radicalmente el curso de los acontecimientos, rectificando aquellas disposiciones..$^{8}$

El io de febrero de I715, Bartolomé comparecía ante uno de los escribanos de La Laguna, reconociendo el establecimiento anterior del vínculo hacia su mujer, aunque ahora imperaba la disolución del mismo, haciendo notar cierto fraude. Señala la misma fuente que Juana de Ocampo le había escrito a Oaxa-

74. Amador, El ajuar..., op. cit., pp. 3 I y 173 (inédito).

75. Fernández, op. cit., p. IOI3.

76. Bonnet, op. cit., p. 213.

77. Tras Juana, la siguiente nombrada es Elvira de Mesa y Castilla; le siguen María Ana, Bárbara y, ahora sí, Luis Bernardo; finalmente, como línea directa, Juan Antonio; siempre queda estipulado entre cada uno que antes del siguiente los derechos serán adquiridos por los segundos hijos de los nombrados. Para asegurar el patronato y manteniendo las mismas disposiciones, siempre y cuando no se cumpla ninguna de las cláusulas anteriores, éste recaerá en "José de Mesa, mi primo, marqués de Torrehermosa, caballero de la orden de Calatrava”, o finalmente en "el alférez mayor Francisco Baltasar de Mesa, caballero de la misma orden". Aнsct, Protocolo notarial 730, doc. cit., ff. I8v-I9r; Cioranescu, Diccionario biográfico..., op. cit., pp. 4I4-4I5.

78. Este asunto fue recogido en su momento por Cioranescu, aunque sólo parcialmente y sin la necesaria interpretación. Idem. 
ca desacreditando a su hijo Luis, lo cual luego hemos entendido pudo ser un recurso en beneficio propio para hacerse con los réditos del patronazgo, si bien ello no queda claro y finalmente no alterará de forma importante nuestro análisis, debido al temprano fallecimiento de aquélla. Al respecto se lee

que don Luis de Mesa y Castilla su hijo legítimo mayor y del otorgante había sin voluntad de la dicha su madre, teniendo buen cabello quitárselo y puesto cabellera no habiendo necesidad, y que en ocasión de las reales fiestas de proclamación de nuestro rey y señor don Felipe $V$ que Dios guarde, se había puesto el dicho don Luis el peor vestido y el más viejo para afrentar a su madre, y que en otra ocasión había el dicho don Luis cortado dos dedos de una mano a Manuela, esclava de color pardo propia de la dicha dońa Juana, y que un día dijo a la susodicha que lo que tenía de bueno era por su padre y no por ella, y que también había dicho que agradeciera que el otorgante vivía que si muriera cada puta fuera de su casa, esto por las hermanas del dicho don Luis; y que otro día arrancó [desenvainó] una daga para su madre, y que ella se mantuvo, y él se salió y se estuvo en casa de don Juan Antonio.79

A tenor de lo anterior y tras establecer diversas relecturas del documento completo, ciertos apuntes del mismo y su hilvanado con otros, además de la propia situación en sí, pensamos que la disolución del vínculo y el hecho de ser finalmente Luis el beneficiario ${ }^{80}$ restan credibilidad al planteamiento de la esposa. Ahora bien, del mismo modo es necesario asentar que, cuando muere Bartolomé en $1728,{ }^{8 \mathrm{I}}$ Luis Bernardo era el único de los herederos posible, pues, como se ha señalado en el testamento de Juana de Ocampo, sus otros hijos ya habían

79. AHSCT, Protocolo notarial 853, escribanía ante Francisco Gerónimo Suárez, disolución del vínculo de Fundación por parte de Bartolomé de Mesa y Castilla, io de febrero de I7I5, ff. 5or-v.

8o. Cioranescu, Diccionario biográfico..., op. cit., pp. 4I4-4I5.

8I. "En treinta de junio de mil setecientos veinte y ocho se enterró en esta parroquia, en la capilla mayor, en su sepulcra maiorum, don Bartolomé de Mesa y Castilla. Aunque se hizo pleito por parte del convento de San Agustín ante don Francisco Gutiérrez, notario público, se mandó depositar en dicho sepulcro por el provisor y vicario general de este obispado. Fue a dicho entierro cura y sochantres, siete capas, ocho pausas, acompañó el beneficio, y asistió a la iglesia y misa, que la dijo el señor Milán. Vestuarios: Afonso y Álvarez. Y asistieron con los de arriba. Murió ab intestato. Llevaron las capas: López, Afonso, Pérez, Álvarez, Rodríguez, López Antonio." Archivo parroquial de Nuestra Señora de la Concepción de La Laguna (depositado en el Archivo Histórico Diocesano de San Cristóbal de La Laguna), lib. $5^{\circ}$ de entierros, ff. 20v-2Ir. Queremos agradecer la cesión de esta importante referencia a Lorenzo Santana. 
fallecido. En este punto nos quedamos con Luis Bernardo como beneficiado de las generosas dádivas del Sahorí, y será su último testamento — realizado a petición de aquél por sus albaceas - el que desvele aspectos de su personalidad $y$, creemos, un posible final para la trama establecida por nosotros.

Rebasados ya los 80 años de edad y declarando "indisposición corporal, postrado en cama, que me pone en el preciso cuidado de la muerte natural, queriendo como quiero hallarme dispuesto y prevenido para tan forzoso trance", Luis abría poder para testar en la ciudad de La Laguna el 3I de octubre de 176I. Se declaró casado con Ana Ruiz de la Guardia, sin descendencia directa, y señaló a sus albaceas —entre ellos su propia esposa—, así como algunas disposiciones puntuales, en especial las de su entierro. ${ }^{82}$ En el largo documento anexo al referido poder, los testamentarios desglosaron de forma pormenorizada las anotaciones dadas, apuntando de entrada que en cumplimiento a las mandas del entierro, éste había sido en el convento de San Diego del Monte, extramuros de la ciudad de La Laguna: "junto al sepulcro en el que lo fue el siervo de Dios fray Juan de Jesús, su especial amigo que fue [...] sin pompas ni vanidad". ${ }^{83}$ Respecto de la particular referencia a fray Juan de Jesús (Icod de los Vinos, I6r5-La Laguna, 1687), cuyo nombre saldrá en repetidas ocasiones a lo largo de las mandas, ésta lleva a presuponer una personalidad de cierto calado religioso en Luis - lo cual se confirmará por su legado—, pero, sobre todo, nos pone en antecedentes de la importancia del religioso tinerfeño en el desenlace de nuestra historia (fig. 8). ${ }^{84}$

En vista de sus múltiples propiedades y los cargos que desempeñó, además de los negocios desarrollados a lo largo de su vida, incluidos al menos los que lo llevaron a realizar un documentado viaje a $\mathrm{México}^{85}$ — quizá siguiendo la estela de su padre-, debió amasar una fortuna considerable. ${ }^{86}$ Sin entrar en la tediosa enumeración de todos sus bienes, basta citar como ejemplos: la casa

82. Aнpsct, Protocolos notariales, 96I, escribanía de Juan Agustín de Palenzuela, ff. 49r5ov.

83. Ibidem, ff. $5 \mathrm{Ir}-\mathrm{r}$.

84. Sobre este personaje véase la parte correspondiente a su biografía en Domingo Martínez de la Peña, La iglesia de San Marcos Evangelista de Icod de los Vinos y vida del siervo de Dios fray Juan de Jesús, Tenerife, Cabildo Insular de Tenerife, 200 I.

85. Cioranescu, Diccionario biográfico..., op. cit., p. 4I5.

86. Para evitar la sucesión de notas, señalamos que todos los apuntes referentes a Luis Bernardo de Mesa provienen del documento abierto por sus albaceas: AHpsct, Protocolos notariales, 961, escribanía de Juan Agustín de Palenzuela, ff. 5rr-73v. 


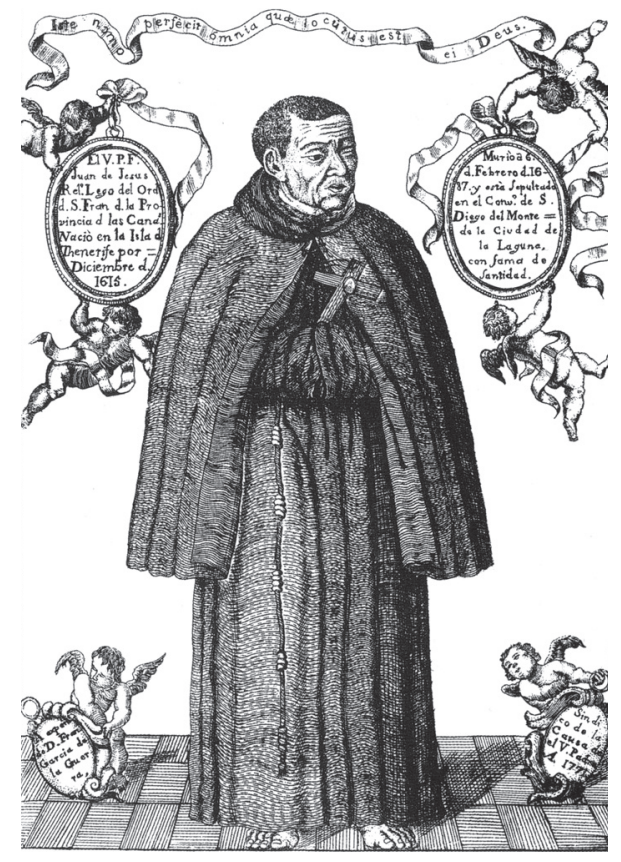

8. Anónimo canario, retrato del siervo de Dios fray Juan de Jesús, posterior a I77I, grabado. Colección del autor.

de su morada en La Laguna, ubicada en el privilegiado enclave de la "plaza de Nuestra Señora de la Concepción y calle de la Carrera”, lindando al poniente con la calle que "va a salir a la otra que viene de San Benito"; otra junto a la Cruz de Juan de Vera; diversos inmuebles en el lugar de Santa Cruz — muy próximos a la calle de San José, también sitio de cierta importancia-, heredados de su familia por varios conductos; otras tierras repartidas por la isla —La Laguna, Tacoronte, El Tablero en el Sobradillo..._- una hacienda en Taganana, además de múltiples tributos acompañados de buenos réditos económicos o en especie.

En el apartado de propiedades es necesario detenernos en la declaración de una "heredad de viñas, con su casa, bodega, lagar y cisterna [...] que dejó en el lugar de Tegueste el Nuevo y heredó el dicho D. Bartolomé de Mesa quien la reedificó y éste de Juan de Molina, su primo, y está junto a San Gonzalo", situándola perfectamente, ${ }^{87}$ a lo cual se añade que "se paga una dobla en cada

87. En el mismo lugar indica otra propiedad similar pero heredada de su abuelo Luis Bernardo de Mesa. Ibidem, f. 54v. 
un año a la ermita de San Gonzalo de dicho lugar", ${ }^{88}$ como adelantábamos y queda recogido en el libro correspondiente a la ermita ya nombrada en otras ocasiones y demuestra, una vez más, el cumplimiento de la voluntad de Molina.

Sigue el documento algo verdaderamente esclarecedor, pues continúa con las tierras correspondientes al Peñón, ${ }^{89}$ refiriéndolas igualmente como heredadas de Molina por Bartolomé e indicando con detalle el testamento del Sahorí y las disposiciones de su padre, las cuales, señala, están "entre los papeles del enunciado de D. Luis con otras diligencias que sobre la testamentaría del dicho don Juan se practicaron por el referido don Bartolomé para el cumplimiento de su voluntad y en las que el dicho confiesa haberlas cumplido". Pero si aquí podemos establecer que queda aclarada parte de las cuestiones desarrolladas, aún debemos dilucidar y concluir con el destino final de la fortuna del Sahorí.

Pues bien, sin abandonar las últimas voluntades de Luis Bernardo de Mesa, sus bienes — de los cuales formaban parte aún pasado el tiempo los pertenecientes a su lejano familiar Molina - se dividieron de manera generosa entre muchos de sus allegados. También una parte significativa se destinó a obras pías. Así, declara que

en el convento de el señor San Francisco de esta ciudad [La Laguna] tenía colocado a su costa el señor San Luis Obispo. En donde por muchos años había hecho su fiesta por ser el de su nombre; y el que le costó muchos [...] Como también andas, mitra y demás que tiene dicho santo, por lo que quería y era su voluntad, que en cada un año perpetuamente para siempre jamás se haga en el referido convento la dicha fiesta, esto es con su procesión y misa cantada por el mes de agosto día de dicho santo poniendo los religiosos la cera necesaria y demás que corresponda. ${ }^{\circ}$

Por supuesto, tampoco olvidaba a su devota Virgen de los Dolores, a la que ya nos hemos referido, y a su parroquia, la de los Remedios:

Expresaron los otorgantes se les comunicó por dicho don Luis que por cuanto el citado don Bartolomé de Mesa su padre, trajo de México a las imágenes de Nuestra

88. Ibidem, ff. $53 \mathrm{v}-54 \mathrm{r}$.

89. "Por delante con el camino que va a Tacoronte y por el poniente camino que va a La Matanza y La Orotava", o sea, hacia el norte de la isla. Ibidem, f. 54r. Asimismo véase AHDT, Fondo Histórico Diocesano, legajo/caja II85, doc. 73, f. 2v.

90. AhPSCt, Protocolos notariales, 96I, escribanía de Juan Agustín de Palenzuela, f. 6or. 
Señora de los Dolores y san Judas que colocó en la iglesia de Nuestra Señora de los Remedios de esta ciudad a quien tenía gran devoción y puso a su costa la plata que guarnece su nicho en donde está el Santísimo Cristo, y dado asimismo las siete lámparas de plata que se hallan en su capilla y a quien costeaba y hacía su fundación dándole lo necesario a dicha santísima imagen ya que el dicho don Luis tenía asimismo devoción y así era su voluntad se diese por su heredera o herederos perpetuamente por siempre jamás cien reales [...] al mayordomo o mayordomos de la cofradía de dicha santísima imagen de los Dolores para ayuda a los costos de su [...] novena y prácticas que se le hacen lo que era su voluntad se pagasen sin [...] perpetuamente de sus bienes y especialmente de la casa de su habitación suerte de peñón y viña inmediata a San Gonzalo que heredó dicho su padre de Juan de Molina siendo como ha de ser de obligación de dichos mayordomos mandarle decir en cada un año una misa cantada el Viernes de Dolores y entregar certificación de la dicha al poseedor o persona que tuviese dichos sus bienes para que le conste haberse cumplido y poder satisfacer dicha cantidad aplicando otra misa por el alma del dicho don Luis, sus padres y mujer y así lo determinó, mandó y comunicó. ${ }^{9 \mathrm{I}}$

Pero la estima por estas devociones particulares no quedaba aquí, porque, como se recoge en otras partes de la misma documentación, volvía a incidir en más misas frente a dicho altar, ${ }^{92} \mathrm{y}$, más aún,

quería y dispuso dicho don Luis había de ser obligación de la dicha su mujer que se diesen los días de su vida todos los años ha de dar de comer a siete pobres, los más necesitados, los Viernes de Dolores de Nuestra Señora y Viernes Santo, en reverencia a los Siete Dolores y Pasión y Muerte de Cristo Nuestro Señor, los que había de sentar en su mesa como tenía de costumbre el citado su marido con la decencia y aseo y asistencia correspondiente con todo lo necesario. Y en el día de san Luis Obispo ha de mandar a los pobres encarcelados media fanega de pan y un barril de vino, cuya devoción tenía dicho don Luis y así lo pidió y comunicó se le ejecutase y le encargasen le encomendaran a Dios. ${ }^{93}$

Para el mismo altar se preocupó en sus mandas testamentarias por la recuperación de un valioso relicario donado por su padre y del cual señala:

91. Ibidem, ff. 62v-63v.

92. Ibidem, f. $67 \mathrm{v}$.

93. Ibidem, ff. 58v-59r. 
les comunicó que el citado don Bartolomé de Mesa había dado una reliquia en un relicario de plata a la iglesia parroquial de Nuestra Seńora de los Remedios, la que todos los ańos se llevaba a ella de su propia casa, hasta que [...] el dicho don Luis se quedaron con ella los mayordomos del Santísimo Cristo de dicho título, la que se colocó en el nicho del señor san Antonio que estaba en el altar de dicho Santísimo Cristo e imagen de los Dolores, la que después a pocos ańos la trataba menos y tuvo entendido se había empeñado por los dichos mayordomos y que así era su voluntad se hagan las diligencias correspondientes dando cuenta a los padres prebendados para que se vuelva a poner y restituya a dicho altar. ${ }^{94}$

A las anteriores cláusulas, y después de saldar sus compromisos como deudor y acreedor, agregó que la fortuna restante se dividiera en tres partes:95 la primera para su esposa; otra para su estimada iglesia de los Remedios, y la última para el convento de recoletos de San Diego del Monte, donde descansarían sus despojos, en especial para enardecer la santidad de su "amigo", el siervo fray Juan de Jesús, a quien finalmente, tras el fallecimiento de su esposa, debía remitirse la parte correspondiente a ella. ${ }^{96}$

A este sustancial tercio se suman otras referencias y donaciones aludidas en varias partes del documento, además de las ya apuntadas en cuanto a su entierro. Asimismo, dejó estipulada la construcción de un oratorio o capilla donde fue su celda y en la cual se mandó enterrar a Luis. También debemos destacar el hecho de haber dejado a su devoto fraile la

viña con su casa, bodega y lagar en dicho lugar de Tegueste el Nuevo que heredó de su padre don Bartolomé de Mesa y éste de don Juan de Molina, su primo, para que con sus frutos que [...] todos los años se fuere aumentando la [...] capilla nueva en [...] a la celda de dicho siervo en donde mandara colocar la referida lámina de Nuestra Señora de los Remedios. Cuya fábrica se había de dar principio con toda brevedad poniendo el síndico a su satisfacción y voluntad persona que cuidase y administrase dicha viña, dándole cuenta de sus réditos y mudando el que le pareciere más acertado como si lo hubiese el mismo don Luis y el referido síndico, lo que

94. Ibidem, f. 7 Ir.

95. Ibidem, f. $70 v$.

96. Ibidem, ff. 7 IV-72v. 
había de ejecutar no como síndico, sino como persona nombrado para ello y así, los dispuso y mandó. ${ }^{97}$

También para el mismo y particular recinto concertaba la celebración de misas en San Diego el I4 de septiembre de cada año con "el Cristo de dicho título [de La Laguna] que tenía en su cabecera para que lo colocasen los religiosos en la celda que fue del siervo".$^{8}$ Como vemos, gran parte de los desvelos de Luis Bernardo de Mesa se encaminaron a la figura de este personaje, para quien no olvidó tampoco dejar más misas y dinero para las ceremonias de beatificación.

Y como toda buena historia siempre deja algún cabo suelto y futuro enlace a nuevas propuestas, éste será el referido juicio eclesiástico, del cual finalmente no estamos en posición de establecer si se realizó ni cuál fue el parecer del tribunal eclesiástico, pero ¿¿tuvieron los prelados toda esta documentación?, ¿fueron verdaderamente justos?, ¿prevalecieron sus intereses frente a la realidad resultante de las pruebas?

\section{En nuestro descargo y como conclusión}

En vista de lo anterior, sólo queda señalar aquello que finalmente intuimos ahora al ser espectadores pasivos del largo contencioso y a la vez analistas de los múltiples hechos avalados por la dispar documentación. En efecto, las disposiciones del Sahorí fueron cumplidas por su estimado primo Bartolomé, si bien pensamos que la realidad del momento, las dificultades del tiempo que aún permaneció este último en América y los intereses tangenciales de los actores secundarios presentes hicieron lógica esta complicada historia.

Ahora bien, finalmente y como elocuente ejemplo, no debe ser de manera gratuita y sí entendible, quizá como expiatorio, el hecho de que la última de las referencias directas del expediente que inició nuestra investigación, y no de manera casual, también final, señale que Luis Bernardo de Mesa "dio a san Juan Evangelista una alhaja en cumplimiento de dicho comunicado, lo que se reguló en trescientos pesos por no haberlo cumplido don Bartolomé, su padre".99 Queda con ello indicada de nuevo la "traición" al donante, pues el

97. Idem.

98. Ibidem, f. $62 \mathrm{v}$.

99. AHDT, Fondo Histórico Diocesano, legajo/caja, I I85, doc. 73, f. 5 v. 
9. A. Vázquez (Canarias), copia llevada a grabado del retrato de la pintura de san Juan Evangelista de la iglesia de Nuestra Señora de la Concepción, I805. La Laguna, Tenerife. Colección del autor.

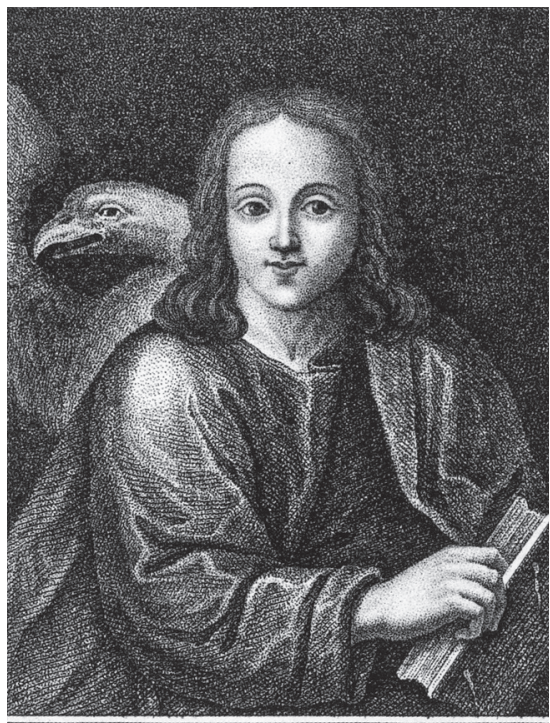

RETRATO DE LA IMAGEN DE S. JUAN EVANGELISTA QUE SE TENERA EN LA TGL ESTA Parroq. de N.S.de la Concepcion de la Ciudad. de la Laguna de Tenerife.

Cir donde sudó por cspacio de to dine daño de 1648: ícupo tiempo cesó milagrasamente la peste que? hatia cmesizaito en dicha Isla.

tiempo transcurrido no debió ser poco, aunque, como puede sobrentenderse, quizá el cumplimiento de su hijo lleve a pensar en los deseos finales de quien la disfrutó sabiendo que era otro, mucho más apreciado por el Sahorí, quien la debiera portar, san Juan, y por ello finalmente se la entregara (fig. 9). ${ }^{\text {Ioo }}$

En definitiva, una larga historia de sinceras devociones y, en parte, de los acostumbrados afanes de vana gloria asociados. Así, aún hoy descansan los despojos corporales del Sahorí en su tumba, a los pies de su devoto san Lorenzo. Nada queda de aquel pequeño templo generador de sus desvelos, fielmente atendidos mientras sus muros se mantuvieron en pie por Bartolomé de Mesa y Castilla, quien

I0o. En cuanto al san Juan indicado, la realidad de las devociones locales en aquellos tiempos lleva a presuponer, como sugiere Carlos Rodríguez Morales, que el sagrado simulacro destinatario fuera el óleo sobre tabla aún presente en la iglesia de Nuestra Señora de la Concepción, el mismo que en 1648 sudó durante 40 días, cesando milagrosamente la peste ya comenzada en la isla. 
al final, aunque mucho tiempo después de su muerte, estamos convencidos, terminó concluyendo las mandas pías bajo su encomienda. A éste le devolvemos el crédito de su devoción por la Virgen en su advocación de Nuestra Señora de los Dolores, foco devocional durante algo más de un siglo en la antigua ciudad de La Laguna. En cuanto a los bienes del primero, éstos verdaderamente fueron disfrutados por su albacea y después por sus herederos indirectos, ajustándose a sus últimos deseos, aunque como el tiempo pone todo en su lugar, el inesperado destinatario final sí fue una obra pía, la de enaltecer el culto a uno de nuestros contados paisanos llamados a subir a los altares, el siervo de Dios fray Juan de Jesús.

A la espera de ansiados nuevos argumentos provenientes del hallazgo de documentación inédita, concluimos con la expiación de Bartolomé de Mesa y Castilla, personaje particular siempre consciente de las encomiendas solicitadas y a las cuales ahora hemos dado algo de nueva luz en favor de restituirle los créditos pertinentes y, en consecuencia, reescribir en parte la historia en la cual anteriormente fuimos partícipes.

\section{A modo de adenda. La devoción del Sahorí a san Lorenzo y su representación en el convento agustino de Oaxaca}

Otra consecuencia del análisis de la documentación encontrada en Canarias y en Oaxaca es el poder comprobar la devoción sincera mantenida por Juan de Molina a san Juan y a san Lorenzo, a quienes pide amparo e intercesión ante el Santísimo, tal como consta en sus mandas testamentarias: "al santo de mi nombre al glorioso mártir san Lorenzo mi devoto”. ${ }^{\text {Ior }}$ Esta predilección ya quedó indicada cuando aludimos a la estipulación para erigir un retablo colateral en la ermita de San Gonzalo, donde figurarían ambos santos a los lados de la Virgen del Rosario. Pero también en Oaxaca dicha veneración, por lo menos al mártir español y en lo concerniente al templo de agustinos de la ciudad, está en parte relacionada con el canario.

Como consta ya desde el poder para testar y luego en su testamento, podía ser sepultado en la "iglesia del señor San Agustín de esta ciudad, en el principal sepulcro de los dos que están al pie del altar portátil del señor san Lorenzo, que se halla en el crucero de la dicha iglesia como entramos a mano derecha 
por ser como son destinados para mí y mis sucesores". ${ }^{102}$ Para ello ostentó su patronazgo previo, pues, como a continuación señaló, era "patrón de dicho altar en conformidad de título que tengo inescriptis de los reverendos padres prior y religiosos del convento de dicha iglesia del señor san Agustín, aprobado y confirmado de los muy reverendos padres provincial y definidores de la provincia del Santo Nombre de Jesús de la ciudad de México a que corresponde dicho convento", todo ello en "atención a una limosna de ochocientos pesos que di de mi propio caudal para ayuda a la obra material de dicho convento". ${ }^{103}$

En efecto, algo más de un año antes, el 29 de octubre de I698, y con la anécdota de protocolizar el nombramiento del patronazgo de Juan de Molina y Barrio sobre el referido altar en papel común, al no encontrar el necesario sellado en el estanco de la ciudad, el escribano Francisco de Quero y el isleño se reunían en la celda del prior de la orden — fray Antonio de los Reyes-, "a son de campana tañida como lo han de uso y costumbre para tratar y conferir las cosas tocantes y pertenecientes al bien propio y utilidad de dicho convento y su iglesia", redactando y firmando ante testigos, entre ellos Bartolomé de Mesa y Castilla, la pertinente investidura. ${ }^{104}$ En ese momento ambas partes acordaban el patronazgo.

Para concluir y en vista de los desvelos del Sahorí por el santo de su devoción, a cuyos pies finalmente debieron quedar sus despojos corporales el 25 de agosto de I699, vale la pena detenernos y estudiar la hechura del mártir espanool aún presente en el templo agustino de la ciudad de Oaxaca, quien en uno u otro sentido está relacionado con el isleño, su patrono, siendo quizá resultado en parte de aquellos ochocientos pesos de oro común ya narrados. Respecto de la capilla y su retablo, en otra referencia inédita en la cual reparamos hasta ahora al dar una última revisión al documento canario de denuncia tantas veces aludido, logramos leer con mucha dificultad en una de las fojas muy dañadas: "cumplió dicho don Bartolomé con la fábrica de una capilla en

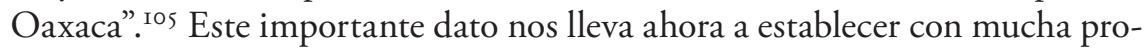
babilidad que durante los años de residencia de Bartolomé en Oaxaca tras la muerte del Sahorí — retornó al archipiélago en I7I4-, debió estar atento a la construcción del retablo, pues el templo en sí se terminó antes. ${ }^{106}$ Con lo

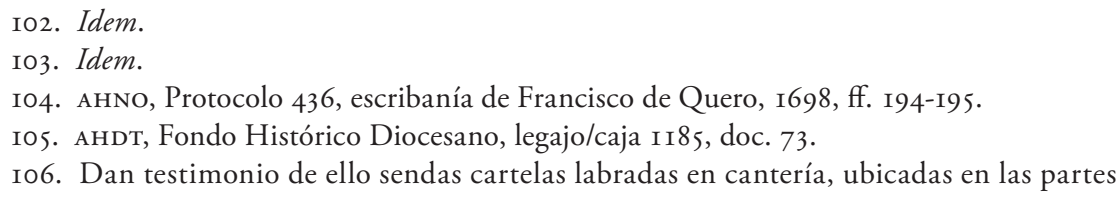


primero, además de mitigar en parte la conciencia planteada sobre la traición de Bartolomé, vuelve a ponerse en valor la devota personalidad del donante $y$, desde ahora, enriquece los conocimientos del arte oaxaqueño con el establecimiento de tan necesarios vínculos, los cuales explican este buen ejemplo de la retablística en la antigua Antequera.

Ubicada en la actualidad en el nicho inferior de cantería en el lateral derecho de la amalgama de retablos formando al principal, la talla de san Lorenzo ha pasado, pese a su notable calidad, prácticamente inadvertida para la historiografía. No sabemos a ciencia cierta cuándo debió ser retirada de su retablo, también conservado, donde pudo ocupar su nicho principal y en el cual hoy se venera una imagen moderna de la Virgen bajo su difundida advocación e iconografía de La Milagrosa, aunque tampoco podemos descartar que quizá, y emulando el retablo opuesto en el crucero, el de san Nicolás Tolentino, y hermano en cuanto a estilo y morfología, estuviera en el segundo cuerpo, en la posible hornacina cubierta en la actualidad por un lienzo, copia de una de las famosas Inmaculadas del genio del barroco español Bartolomé Esteban Murillo (fig. Io).

Se trata de una imagen en madera tallada y policromada de bulto redondo y tamaño natural, en la cual el mártir aragonés mantiene la iconografía tradicional de sus simulacros escultóricos; de pie, vistiendo sotana cubierta por alba, revestido con la dalmática de diácono, y por la postura de sus manos se infiere fácilmente que en la diestra debió sujetar la parrilla, símbolo de su tormento, mientras en la izquierda sostenía el libro abierto de los Evangelios, ambos complementos perdidos.

Las labores del trabajo escultórico son notables, principalmente en cabeza y manos. En la primera se representa un rostro joven de semblante austero, bien trazado en su anatomía y elaboración de detalles. El cabello ensortijado se distribuye en mechones acanalados de gubia y crestas suaves. En las manos, así como en la cabeza, se define bien la anatomía, con especial énfasis en el remarcado de tendones y largos dedos. Las vestimentas inferiores, túnica y alba, contrastan en el tallado de sus plegados con la rectitud de la dalmática, ésta, siguiendo lo real del tejido y condicionado por los bordados y el forro de la prenda. ${ }^{107}$

inferiores de las hornacinas laterales del primer cuerpo de la fachada, donde así se especifica.

I07. Por la morfología en el tallado y algunos detalles coincidentes, podría relacionarse con 
Io. Anónimo novohispano, imagen de san Lorenzo, primer tercio del siglo xviII. Iglesia de San Agustín, Oaxaca.

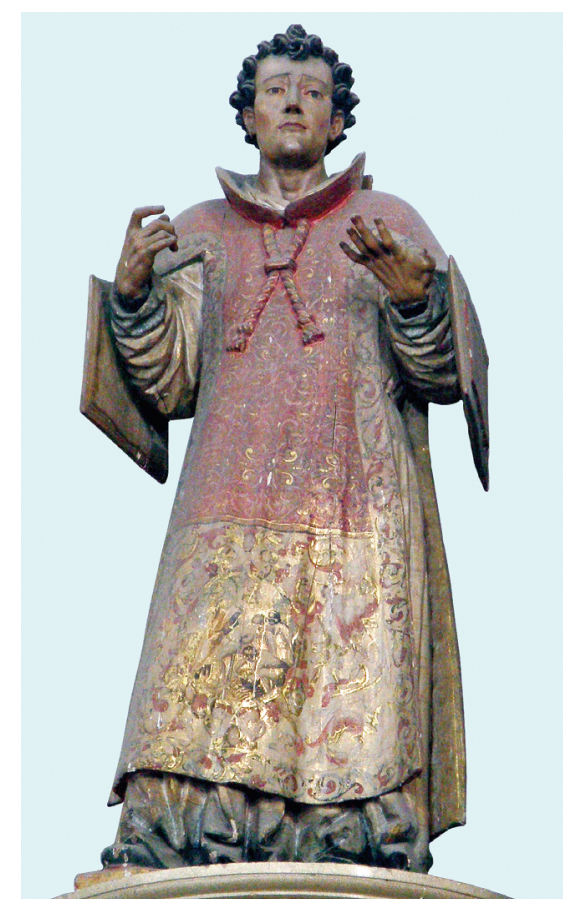

A la par de los anteriores trabajos y como su indudable complemento, la policromía es sobresaliente. Las carnaciones, pese a la degeneración de los barnices que la amarillean y los evidentes cúmulos de polvo depositados con el tiempo, muestran una elaboración esmerada. En ella destacan los matices bien entonados y fundidos de las partes sonrosadas o la tonalidad más oscura de la incipiente barba. Frente a la decoración sencilla de las prendas inferiores - donde prevalecen los esgrafiados sencillos y ciertos detalles a punta de pincel para la imitación de los encajes, complicados de analizar por la lejanía y dificultad de acceso-, en la dalmática el anónimo policromador se abocó a desplegar lo mejor de su arte.

Esta prenda sigue la tradición en su corte de las vestimentas de moda para el momento, el tránsito entre los siglos XVII al XVIII y décadas próximas. Lo

las tallas de san Antonio - en una de las hornacinas laterales opuestas en el altar mayor-, y principalmente con san Nicolás Tolentino del retablo hermano del que en su origen debió presidir nuestra obra. 
mismo ocurre en la decoración plasmada en el tejido general, el rojo, donde se remedan modelos textiles de impronta vegetal y simetría en el concatenado de los motivos, éstos realizados a punta de pincel, con degradaciones en el tono, a modo de aguadas ${ }^{108}$ y detalles en oro y blanco. Sobre los galones, anchos con predominio del blanco, se imitan bordados de rameados a punta de pincel tendientes a enroscarse de manera caprichosa. Lo más interesante, como es habitual en esta prenda e iconografía, es la decoración del cuadrante inferior delantero en la cual, circundada por una profusa ornamentación, destacan las llamadas miniaturas ${ }^{109}$ de policromía y en ella- formando parte de un tondo- se representa el martirio del santo (fig. I I). La belleza de esta particular decoración de la casulla bien vale un análisis detenido también, pues no sólo pone en valor la obra, destacándola, sino también, de su interpretación, podemos establecer ciertas referencias en cuanto a origen, estilo y época.

$\mathrm{Si}$ comenzamos por el motivo central, la miniatura representando el martirio, se puede comprobar que ésta sigue la tradición iconográfica. A pesar de no haber localizado la fuente exacta de donde proviene este ejemplo — quizá algún grabado aportado por los frailes al pintor-, la reiteración de elementos y figuras con otros por todos conocidos es evidente. Trabajada a modo de pintura bordada, la figura del santo, casi desnudo y con las manos atadas a la espalda, es el punto central de la composición. Éste es apresado por el cuello por un soldado que lo mantiene sujeto a la parrilla, mientras otro personaje, de rodillas, prepara el material para el fuego. En el lado opuesto, una figura masculina con la cabeza cubierta - seguramente corresponde con un sacerdote pagano seguidor de los edictos de Valeriano, a los que sucumbió el mártir español- sugiere injurias sobre la fe profesada por Lorenzo y por ello alza la mano derecha seńalando con un dedo hacia los cielos. El reconocimiento de santidad queda rubricado por el rompimiento de gloria superior de donde surge un ángel portador de la palma y la corona de laurel, elementos significativos del martirio y la victoria.

Enmarca la escena una vistosa cartela de tipo correiforme complementada por una profusa labor de hojarasca para rellenar el espacio del cuarterón

I08. Según el Diccionario de autoridades de I732, por este tipo de aguada se entiende "una voz de pintura, y son los colores de negro y blanco con que sólo pintan, ya en lienzo, ya en papel, o en pared, pintando flojamente con sombras y luces. Y también se llaman así a los dibujos de otra cualquier tinta sola: como encarnada, azul, verde, etc."; apud Fernando R. Bartolomé García, La policromía barroca en Álava, Diputación Foral de Álava, 200I, p. 359.

109. Ibidem, pp. 163-164. 
II. Anónimo

novohispano, detalle

del martirio de san

Lorenzo, que se localiza

en la dalmática de la

imagen de san Lorenzo,

primer tercio del siglo

Xviri. Iglesia de San

Agustín, Oaxaca.

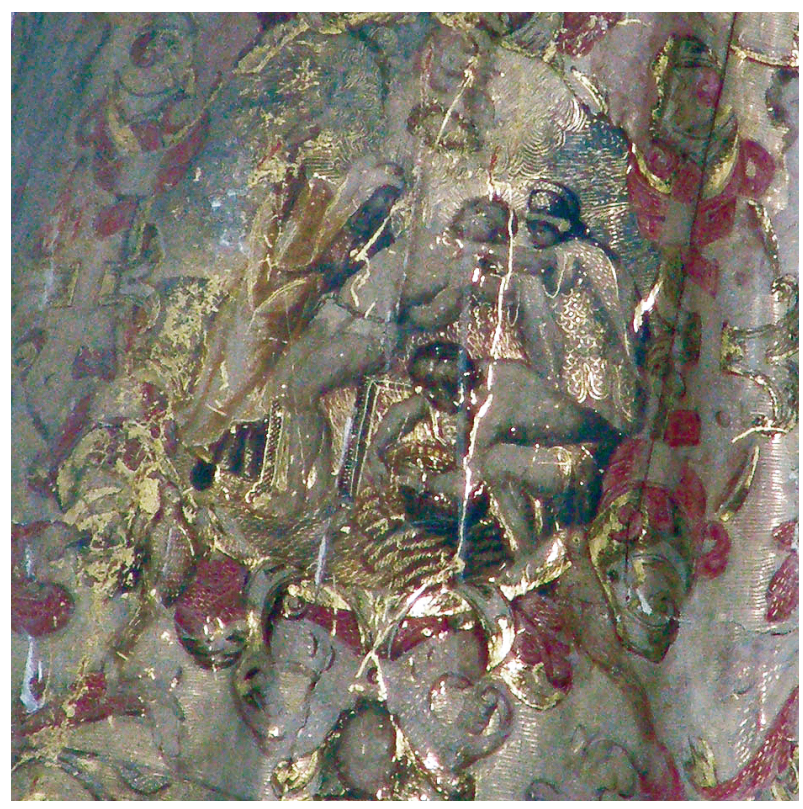

que los delimita, donde destacan cabezas, niños, aves y personajes híbridos. La aparición de estos últimos y su conjugación no parece casual o meramente ornamental, pues, como a continuación argumentaremos, habla de unos modelos en tránsito marcados por la propia Iglesia y que hasta ahora, según sabemos, no han sido analizados para la plástica de los estofados escultóricos novohispanos. ${ }^{\text {IIO }}$

Condicionados por los preceptos contrarreformistas derivados del Concilio de Trento y siguiendo las sugerencias de estudios como los realizados para el norte español por Echevarría Goñi y Fernando Bartolomé, en la decoración estudiada comprobamos cómo podemos establecer su relación directa con los motivos peninsulares pendientes de la evolución del grutesco. Señalan los

i io. A modo de apunte debemos señalar cómo en una de las letras capitulares de un himnario conservado en la Catedral de México, concretamente la correspondiente a la C, podemos establecer ciertas concomitancias con el fondo ornamental de la parte tratada en la talla oaxaqueña. Este trabajo de iluminación fue en su momento relacionado por Tovar de Teresa con el arte de Luis Lagarto y fechable antes de su marcha a la catedral angelopolitana a finales del siglo xvi. Guillermo Tovar de Teresa, El arte de los Lagarto, México, Fomento Cultural Banamex, 1988, pp. 66-7I. Para consultar la ilustración véase la página 7I. 
anteriores investigadores que tras Trento y los pertinentes concilios provinciales, sínodos diocesanos e Inquisición se optará por un mayor cuidado para las representaciones, entendiendo que en éstas estaban abocadas a ser elementos de carácter doctrinal y propagandístico. ${ }^{I I I}$ Luego, a lo largo del siglo XVII, las vestimentas y paños de retablos recubiertos por formas y motivos ornamentales se irán depurando, perdiendo aquellos motivos fantásticos y oníricos que desde lo medieval y ya en el Renacimiento — con sus fuentes directas de interpretación- protagonizaron la centuria anterior.

Aludamos como mejor exponente a lo dicho por Francisco Pacheco, quien en su tratado de la pintura, cuando aborda el capítulo III en relación con el estofado, sugiere el abandono o relegado de aquellos motivos - aunque para ese momento ya habían sufrido un notable cambio- y aboga por plasmar en las decoraciones serafines, niños, pájaros y frutas junto a los rameados. ${ }^{\text {II2 }}$ Estos motivos "vivos" y a "imitación del natural", ya analizados de manera concienzuda por Echevarría Goñi, entrarán en una irremediable evolución, y así, en sintonía con lo representado en la dalmática del san Lorenzo oaxaqueño,

las aves y los niños que articulan en el ritmo que imprimen los tallos vegetales o rameados, simplificaciones naturalistas de los grutescos, que, a modo de roleos, se repiten en los frisos, fondos de cajas y mantos y tienden a engrosar a medida que avanza el siglo XvII, mientras que las cartelas correiformes con minúsculos paisajes y puntas de diamante actúan de ejes de simetría. ${ }^{113}$

Por lo anterior, podemos afirmar que las decoraciones analizadas en este artículo, pese a ser tan tardías, deben ser encuadradas o derivadas en esa corriente contrarreformista, extendida durante gran parte del siglo XVII, de clara naturaleza barroca. Pero en nuestro afán de acortar distancias y marcar las pautas de aproximación y definición necesarias, también pensamos que nos encontramos ante un novedoso ejemplo novohispano para el cual reclamamos los términos barrocos indicados por Fernando R. Bartolomé García: papelas de todos colores o grutesco, este último siempre como parte del desarrollo pro-

II I. Bartolomé García, op. cit., p. I85.

II2. Francisco Pacheco, El arte de la pintura (1649), lib. III, cap. III, Madrid, Cátedra, I990, pp. 462-463.

I 13. Pedro Echevarría Goñi, Policromía del Renacimiento en Navarra, Pamplona, Gobierno de Navarra, 1990, p. I46. 
DOI: http://dx.doi.org/10.22201/iie.18703062e.2012.101.2428

DE OAXACA A CANARIAS

puesto por el anterior investigador. ${ }^{\mathrm{II} 4}$ A hora bien, como particularidad y quizá como un elemento retardatario, evocador de su remoto origen formal, no podemos olvidar sendas figuras híbridas, parte superior humana e inferior vegetal, que de igual manera se localizan en la policromía en estudio y vienen a recalcar de forma fehaciente las aseveraciones propuestas. $\stackrel{\xi}{\$}$

I 4. Bartolomé García, op. cit., pp. 95-97.

N.B. Quiero agradecer a Carlos Rodríguez Morales, Selene García Jiménez, Juan Alejandro Lorenzo Lima y Andrés de Leo, quienes me ayudaron de forma inestimable en el presente y complicado trabajo.

* Artículo recibido el 17 de febrero de 20I2; aceptado el 5 de junio de 2012. 